\title{
Defective goblet cell exocytosis contributes to murine cystic fibrosis-associated intestinal disease
}

\author{
Jinghua Liu, ${ }^{1}$ Nancy M. Walker, ${ }^{1}$ Akifumi Ootani, ${ }^{2}$ Ashlee M. Strubberg, ${ }^{3}$ and Lane L. Clarke ${ }^{1,3}$ \\ 'Dalton Cardiovascular Research Center, University of Missouri, Columbia, Missouri, USA. ${ }^{2}$ Akimoto Hospital, Fukuoka, Japan. ${ }^{3}$ Department of Biomedical Sciences, University of Missouri, Columbia, Missouri, USA.
}

\begin{abstract}
Cystic fibrosis (CF) intestinal disease is associated with the pathological manifestation mucoviscidosis, which is the secretion of tenacious, viscid mucus that plugs ducts and glands of epithelial-lined organs. Goblet cells are the principal cell type involved in exocytosis of mucin granules; however, little is known about the exocytotic process of goblet cells in the CF intestine. Using intestinal organoids from a CF mouse model, we determined that CF goblet cells have altered exocytotic dynamics, which involved intrathecal granule swelling that was abruptly followed by incomplete release of partially decondensated mucus. Some CF goblet cells exhibited an ectopic granule location and distorted cellular morphology, a phenotype that is consistent with retrograde intracellular granule movement during exocytosis. Increasing the luminal concentration of bicarbonate, which mimics CF transmembrane conductance regulator-mediated anion secretion, increased spontaneous degranulation in WT goblet cells and improved exocytotic dynamics in CF goblet cells; however, there was still an apparent incoordination between granule decondensation and exocytosis in the CF goblet cells. Compared with those within WT goblet cells, mucin granules within CF goblet cells had an alkaline $\mathrm{pH}$, which may adversely affect the polyionic composition of the mucins. Together, these findings indicate that goblet cell dysfunction is an epithelial-autonomous defect in the CF intestine that likely contributes to the pathology of mucoviscidosis and the intestinal manifestations of obstruction and inflammation.
\end{abstract}

\section{Introduction}

Cystic fibrosis (CF), an autosomal recessive disease, is caused by loss-of-activity mutations in CF transmembrane conductance regulator (CFTR) (1), an epithelial anion channel largely responsible for transepithelial secretion of chloride and bicarbonate. One of the more perplexing manifestations of $\mathrm{CF}$ is mucoviscidosis. Often used synonymously for CF, mucoviscidosis describes the pathology of tenacious, viscid mucus produced in the glands and ducts of affected organs, including the airways, intestine, pancreatic ducts, biliary ducts, and cervical glands. Mucoviscidosis of epithelial structures and associated plugging of glands and ducts leads to degeneration by inflammation, alters epithelial-microbial interactions, and compromises innate immunity (2). Although each organ affected in CF normally produces a different composition of mucins, all manifest mucoviscidosis, which suggests a common underlying pathogenesis $(3,4)$. In CF epithelia, a deficit in the capacity for salt and water secretion is intuitively associated with the production of mucus with altered rheological properties, i.e., dehydrated mucus. However, this hypothesis may not account fully for the pathology of CF mucoviscidosis based on several observations that include limited effectiveness of aerosolized hypertonic saline for CF lung clearance $(5,6)$, failure of mucus release from CF mouse intestine bathed luminally with physiological Ringer's solutions (7), and mucus plugging of intestinal crypts in adult CF mice despite life-long osmotic laxative therapy (2).

Conflict of interest: The authors have declared that no conflict of interest exists Submitted: September 30, 2013; Accepted: December 18, 2014.

Reference information: J Clin Invest. 2015;125(3):1056-1068. doi:10.1172/JCI73193.
Recent breakthroughs in CF mucoviscidosis research have focused on the critical role of $\mathrm{HCO}_{3}^{-}$in mucus biology and the underlying deficit of CFTR-mediated $\mathrm{HCO}_{3}^{-}$transport. Studies of isolated mouse intestine provide indirect evidence that approximately $50 \%$ of stimulated mucus release requires CFTR-dependent $\mathrm{HCO}_{3}^{-}$secretion (7). It was hypothesized that $\mathrm{HCO}_{3}^{-}$secretion during exocytosis may be important for mucus expansion by neutralizing protons and precipitating $\mathrm{Ca}^{2+}$ ions that, during granule condensation, shield the repulsive forces of high-density anionic sites on mucin glycoproteins (8). Subsequent studies by Gustafsson et al. demonstrated that a high concentration of luminal $\mathrm{HCO}_{3}{ }^{-}(115 \mathrm{mM})$, intended to recapitulate stimulated $\mathrm{HCO}_{3}^{-}$ secretion by adjacent CFTR-replete enterocytes, significantly decreased the adherence of mucus to the surface of the CF mouse ileum (9). Moreover, it was recently shown in CF mouse ileum that a high luminal $\mathrm{HCO}_{3}{ }^{-}$concentration provides unfolding of MUC2 that is likely necessary for cleavage by the brush border metalloendopeptidase meprin $\beta$ and subsequent release of mucus from the mucosal surface of the intestine (10).

Direct involvement of CFTR in goblet cell function has been controversial, largely due to the limitations of immunolocalization. Studies of human tracheal gland mucous cells and murine gallbladder columnar cells demonstrated CFTR expression in the cellular membrane/intracellular compartments and mucin granule membrane, respectively $(11,12)$. However, subsequent studies were unable to find significant CFTR expression in goblet cells of human airways and intestine $(13,14)$ or mouse colon (15). An early study reported a role of CFTR in regulating organellar $\mathrm{pH}$ by purportedly providing counter anions to support 


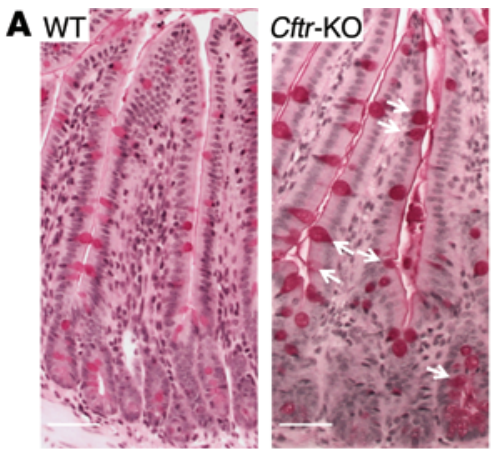

B
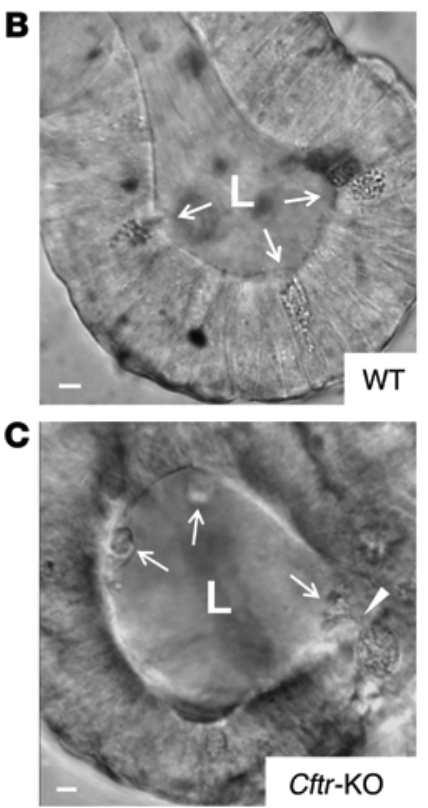

D

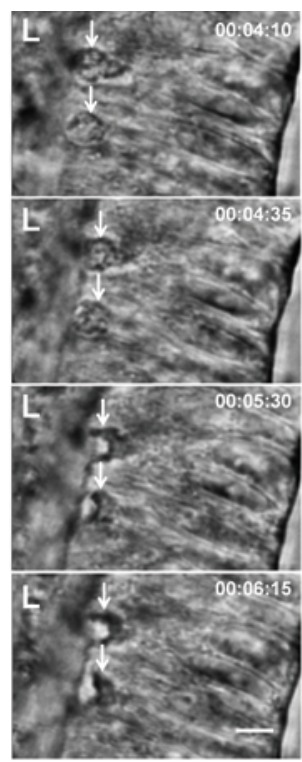

E

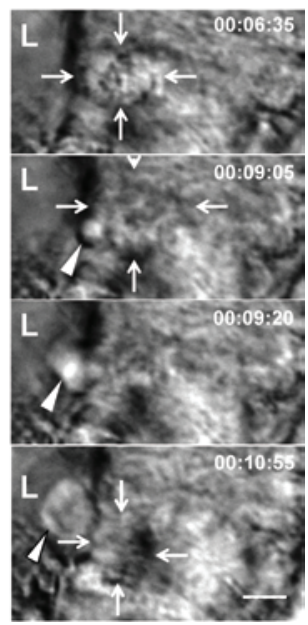

organellar acidification by the vacuolar $\mathrm{H}^{+}$-ATPase (V-ATPase) (16). Others have both supported $(17,18)$ and refuted $(19-21)$ the contention that lysosomal/trans-Golgi pH is alkaline in CFTRdeficient cells. Recently, studies of human airway epithelium showed immunolocalization of CFTR with MUC5AC in isolated mucin granules and, further, demonstrated a CFTR-dependent $\mathrm{Cl}^{-}$conductance that enhanced granule acidification (22). Granule $\mathrm{pH}$ can affect mucus biology in several ways. An acidic $\mathrm{pH}$ in the secretory pathway of mucus-producing cells is required for autocatalysis (23), N-terminal trimerization of MUC2 (8), and granule organization (24). It is also known that an acidic granule $\mathrm{pH}$ facilitates $\mathrm{K}^{+} / \mathrm{Ca}^{2+}$ ion exchange at the granule membrane during stimulation of exocytosis, which may signal granule release as well as contribute to the initiation of exocytosis (25). In other secretory cells, an alkaline $\mathrm{pH}$ of the secretory granules is known to slow the rate of exocytosis (26). Thus, the question of mucin granule $\mathrm{pH}$ in $\mathrm{CF}$ goblet cells has important implications with regard to mucoviscidosis.

Few studies have investigated the dynamics of $\mathrm{CF}$ goblet cell function in a well-differentiated epithelium. Studies of human airway epithelial explants found that CF goblet cells had normal rates of degranulation, as estimated en face by temporal image

Figure 1. Incomplete mucin release by $\mathbf{C f t r - K O}$ goblet cells. (A) PASstained section of $100 \mu \mathrm{M} \mathrm{CCH}$-stimulated intestine from WT (left) and Cftr-KO (right) mice. White arrows, Cftr-KO goblet cells with attached luminal mucus. (B) Transverse view of WT enteroid crypt during $100 \mu \mathrm{M} \mathrm{CCH}$ stimulation of goblet cell exocytosis. Arrows, goblet cells; L, crypt lumen. (C) Transverse view of Cftr-KO enteroid crypt during CCH stimulation of goblet cell exocytosis. White arrows, goblet cells with attached luminal mucus blebs; arrowhead, luminal extension of released mucus connected to granule cluster in theca. (D) Time-lapse microscopy of WT enteroid showing orderly progression of CCH-stimulated exocytosis by 2 goblet cells (white arrows). Top panel, goblet cells 2.25 minutes after $\mathrm{CCH}$; panel 2 , early exocytosis; panel 3 , cupping at the apical aspect of the goblet cell during exocytosis; panel 4, ongoing exocytosis. (E) Time-lapse microscopy of Cftr-KO enteroid during CCH stimulation of goblet cell exocytosis. White arrows indicate the perimeter of granule cluster. Top panel, goblet cell 1.25 minutes after $\mathrm{CCH}$; panel 2, enlarged granule cluster and enlargement of individual granule within theca (arrowhead); panel 3, exocytosis of enlarged granule (arrowhead); and panel 4, formation of a mucus bleb protruding into lumen (arrowhead). Note reduced size of granule cluster. Scale bars: $50 \mu \mathrm{m}$ (A); $10 \mu \mathrm{m}$ (B-E).

subtraction, in response to luminal purinergic agonists (ATP, UTP) (27). However, an assessment of epithelial mucin in endobronchial biopsies found a $50 \%$ increase in the mucin volume of $\mathrm{CF}$ airway goblet cells and evidence of luminal mucus anchored to goblet cell thecal contents (henceforth referred to as luminal "blebbing") (28). A similar phenomenon occurs in the CF intestine, where ultrastructural studies have shown evidence of abnormal goblet cell exocytosis that manifests as mucus blebbing of partially decondensated mucin granules (29). Studies at the level of the goblet/mucous cell take on added significance in that recent organ-level studies of a porcine CF model show that impaired mucus detachment from submucosal gland ducts is primarily responsible for the deficit of mucociliary clearance in CF respiratory disease (30).

In the present study, goblet cell function during stimulated exocytosis was investigated using WT and $\mathrm{Cftr}$-KO mouse intestine. The Cftr-KO mouse recapitulates the major aspects of human CF intestinal disease, including goblet cell hyperplasia, adherent secreted mucus, low-grade bowel inflammation, and overt obstructive disease that is prevented by osmotic laxative maintenance therapy $(2,31-34)$. Real-time evaluation of the degranulation process was possible through the use of small intestinal organoids (enteroids), which provide visual access to the longitudinal axis of mature goblet cells within the native setting of the crypt/lower villus, i.e., surrounded by enterocytes and other cell lineages of the intestinal epithelium $(35,36)$. Cftr-KO enteroids also provide the opportunity to evaluate the epithelialautonomous effect of CFTR loss on goblet cell function by eliminating confounding factors inherent to the $\mathrm{CF}$ intestinal environment, i.e., dysbiosis, inflammation, and submucosal/systemic disease alterations. Our studies provide evidence of altered exocytotic dynamics, incomplete mucus discharge, ectopic intracellular granule location, and increased $\mathrm{pH}$ of mucin granules in $\mathrm{Cftr}$-KO goblet cells. Further, it is shown that provision of high luminal $\mathrm{HCO}_{3}{ }^{-}$concentration to $\mathrm{Cft}$ - $\mathrm{KO}$ goblet cells improves exocytosis and granule decondensation, supporting the possibility that oral bicarbonate therapy may be useful in the treatment of CF intestinal disease. 
A

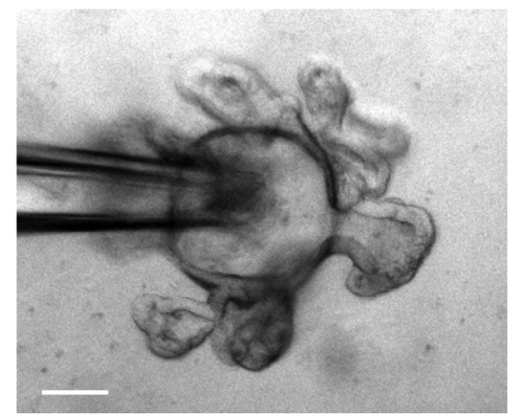

C

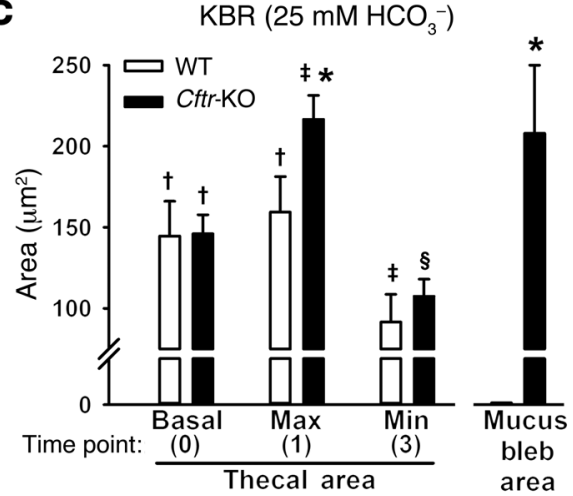

B

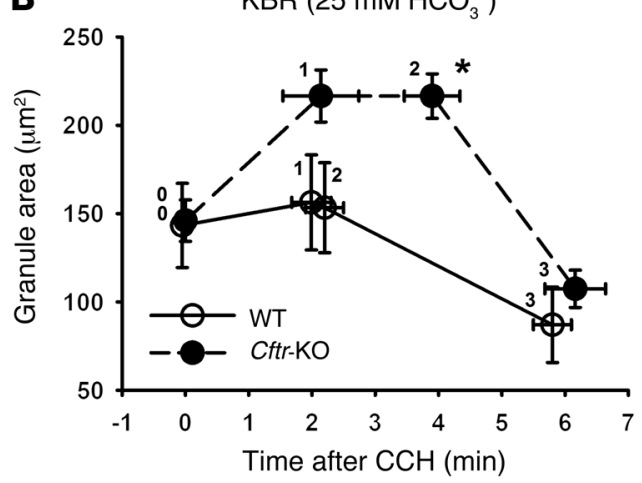

D $\quad \mathrm{KBR}\left(25 \mathrm{mM} \mathrm{HCO}_{3}^{-}\right)$

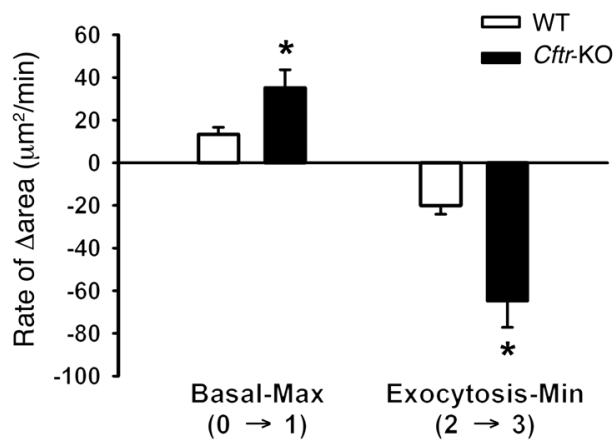

Figure 2. Dynamics of goblet cell exocytosis induced by $\mathbf{1 0 0} \mu \mathrm{M}$ CCH in WT and Cftr-KO enteroids. (A) Luminal superfusion of enteroid using a micropipette. Basolateral superfusate flow is from right to left. Scale bar: $50 \mu \mathrm{m}$. (B) Dynamics of CCH-stimulated exocytosis: 0 , granule area immediately prior to CCH (basal); 1, time point when maximal granule area attained after CCH (max); 2 , granule area at first visible evidence of exocytosis; 3 , time point of minimal granule area attained after exocytosis (min). Lines between points do not represent data, but are provided to illustrate the continuous nature of the exocytotic process and a visual estimate of rates of change in granule area between basal $\rightarrow$ maximum and exocytosis $\rightarrow$ minimum. ${ }^{*} P<0.05$, time period between $1 \rightarrow 2$ is significantly longer than in WT by $t$ test. (C) Statistical analyses of cross-sectional area of granule cluster at basal (time point 0 ), maximum (time point 1), and minimum (time point 3). Mucus bleb area is equal to cross-sectional area of luminal bleb from a perimeter line drawn between the apical membranes of adjacent enterocytes and outlining the mass in the crypt lumen after CCH-induced exocytosis. ${ }^{+, \neq, \$}$ Within group, means with different symbols are statistically different by ANOVA with post-hoc Tukey's test. ${ }^{*} P<0.05$, significantly different from WT by $t$ test. (D) Rate of change in granule area between basal and maximum (time points $0 \rightarrow 1$ ) and between exocytosis and minimum (time points $2 \rightarrow 3$ ) after CCH exposure. ${ }^{*} P<0.05$, significantly different from WT by $t$ test. $n=8-14$ goblet cells in enteroids from 4 WT and Cftr-KO sex-matched littermate pairs.

\section{Results}

Postexocytotic mucus retention by Cftr-KO goblet cells is an epithelialautonomous effect of CFTR loss. Similar to the evidence of goblet cell mucus retention in human CF intestine (29), mucus bleb attachment to the content of goblet cell thecae is frequently observed in intestinal sections from Cftr-KO mice (10). As shown by the comparison to WT intestine in Figure 1A, the histological appearance of Cftr-KO intestine following carbachol $(\mathrm{CCH})$ stimulation of exocytosis typically includes goblet cells that appear distended with mucus and others in which the granule cluster retains a connection with secreted mucus. The abnormal environment of the CF intestine (dysbiosis, inflammation, dysmotility, deficiencies of innate immunity, obstructive disease) may affect goblet cell function (2, 32, 33, 37-43); therefore, stimulated goblet cell exocytosis was compared in primary enteroid cultures taken from WT and Cftr-KO sex-matched littermates. As shown in Figure 1, B and C, goblet cells in crypts from the WT enteroids exhibited cavitation at the luminal pole following treatment with $\mathrm{CCH}$, whereas $\mathrm{Cftr}$ $\mathrm{KO}$ goblet cells often form luminal mucus blebs attached to the thecal contents (also see higher magnification in Supplemental Figure 1; supplemental material available online with this article; doi:10.1172/JCI73193DS1). Using video microscopy to follow the exocytotic process in real time (Figure 1D and Supplemental Video 1), $\mathrm{CCH}$ stimulation of exocytosis in WT enteroids was observed to be an orderly process resulting in the loss of granules from the apical to basal pole of the theca in a central radial pattern, i.e., cupping. A wispy, translucent stream from the luminal thecal border was occasionally observed, but accumulation of degranulated mucus, i.e., a mucus bleb, at the luminal border was not observed. In contrast (see Figure 1E and Supplemental Video 2), the granule cluster of Cftr-KO goblet cells treated with $\mathrm{CCH}$ initially underwent an increase in size, often with visible expansion of granules within the theca. Subsequent expulsion, sometimes appearing as a rupture of the apical membrane, occurred with formation of a transparent mucus bleb at the luminal surface of the goblet cell. Cupping of the goblet cell theca was not observed. Notably, ectopic exocytosis with formation of a transparent mucus bleb was occasionally evident at the basal aspect of the epithelium. 

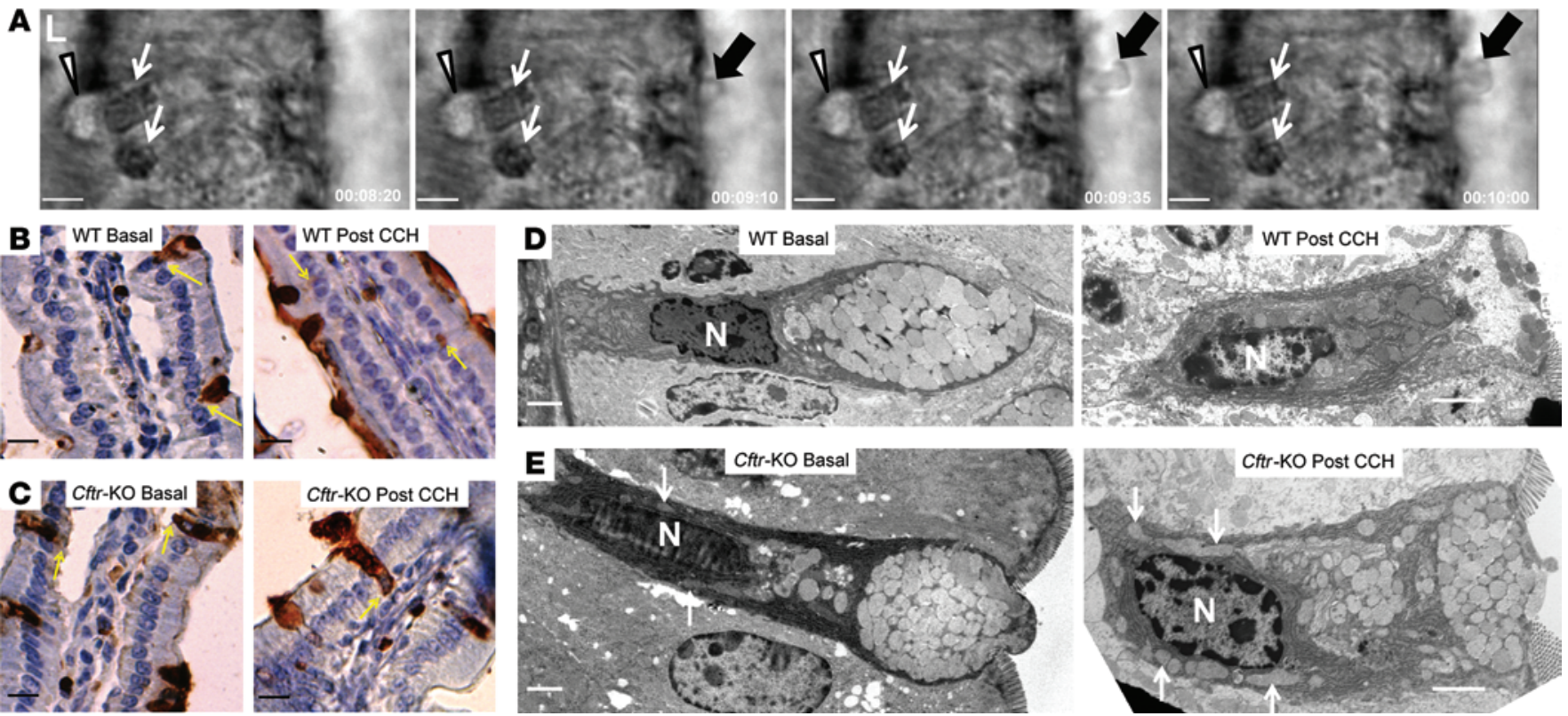

Figure 3. Ectopic mucin granule location in Cftr-KO goblet cells. (A) Time-lapse microscopy showing basolateral mucus bleb formation in a Cftr-KO enteroid. White arrows, goblet cells 3.25 minutes after exposure to $100 \mu \mathrm{M} \mathrm{CCH;} \mathrm{arrowhead,} \mathrm{formation} \mathrm{of} \mathrm{a} \mathrm{luminal} \mathrm{mucus} \mathrm{bleb;} \mathrm{black} \mathrm{arrows,} \mathrm{basal} \mathrm{blebs;}$ L, lumen of enteroid. (B and C) MUC2 immunostaining of untreated (basal) and CCH-treated (post-CCH) villi from WT (B) and Cftr-KO (C) intestine incubated in $25 \mathrm{mM} \mathrm{HCO}_{3}^{-} \mathrm{KBR}$ at $37^{\circ} \mathrm{C}$ for 20 minutes. Yellow arrows, basilar extent of MUC2 immunostaining within goblet cells. Hematoxylin counterstain. Villi are oriented with serosal aspect at base of photomicrograph. Note MUC2 immunostaining of luminal mucus bleb and extension of MUC2 to basement membrane in both basal and CCH-treated goblet cells of $C f t r-K O$ intestine. Studies are representative of 6 similar experiments. (D and E) TEM of WT (D) and Cftr-KO (E) goblet cells before and after CCH treatment (same experimental method as in $\mathbf{B}$ and $\mathbf{C}$ ). N, nucleus; white arrows, ectopic granulae about nucleus in Cftr-KO goblet cell. Representative of 4 similar experiments. Scale bars: $10 \mu \mathrm{m}$ (A-C); $2 \mu \mathrm{m}$ (D and E).

Altered dynamics of CCH-stimulated exocytosis in Cftr-KO goblet cells. To ensure uniform luminal and basolateral membrane exposure of the enteroids to a physiological Kreb's bicarbonate Ringer's (KBR) solution $\left(25 \mathrm{mM} \mathrm{NaHCO}, 5 \% \mathrm{CO}_{2}\right)$, a series of studies was performed in which the interiors of gel-immobilized enteroids were superfused using a glass micropipette $(\sim 1-2 \mu \mathrm{l} /$ $\mathrm{min}$, see Figure 2A). The micropipette was inserted into a puncture of the enteroid central cavity opposite of the flow direction of the bath superfusion $(\sim 3 \mathrm{ml} / \mathrm{min})$. Luminal superfusion was denoted by a visible distention of the lumen and the flushing of debris from the enteroid interior at the puncture site. Goblet cells for analysis were chosen for morphological maturity based on cell position above +4 , small granule size relative to Paneth and "intermediate" cells, and a granule cluster positioned primarily in the apical $30 \%$ of the cell.

Postacquisition morphometric analysis of the goblet cell granule area before and during exposure to $100 \mu \mathrm{M} \mathrm{CCH}$ identified landmark events during the exocytotic process. Exocytosis in WT enteroids occurred in $87.5 \%$ (7 of 8) of the goblet cells and was observed as a progressive disappearance of individual granules from the apical pole. Exocytosis in the Cftr-KO enteroids occurred in $57.1 \%$ ( 8 of 14) of the goblet cells and typically resulted in the formation of a luminal mucus bleb during loss of granules from the apical pole (in 1 additional case, compound exocytosis was entirely localized to the basal aspect of the epithelium). As shown in Figure 2, B and C, the cross-sectional granule areas of WT and Cftr-KO goblet cells were identical under basal conditions. Following $\mathrm{CCH}$ exposure, the $\mathrm{Cftr}$-KO granule area increased in size, whereas WT goblet cells exhibited a small, nonsignificant increase in granule area (time points $0 \rightarrow 1$ ). The increased area for each genotype occurred within approximately the same time period (Figure 2B), thus yielding a greater overall rate of increase in the $\mathrm{Cftr}$-KO goblet cells (Figure 2D, basal-maximum). There was no corresponding change in cell volume as indexed by cell height (44) (WT: basal $=50.3 \pm 2.7 \mu \mathrm{m}$ and maximum $=50.9 \pm$ $2.6 \mu \mathrm{m}, \mathrm{NS}$; Cftr-KO: basal $=52.6 \pm 1.6 \mu \mathrm{m}$ and maximum $=53.2$ $\pm 1.8 \mu \mathrm{m}, \mathrm{NS} ; n=8-12)$. The small increase in granule area in WT goblet cells was immediately followed by individual granule loss from the apical pole, which continued until a steady-state minimal granule area was attained ( $\sim 4$ minutes). In contrast, $C f t r-\mathrm{KO}$ goblet cells underwent a significant delay after attaining maximal granule area before there was evidence of degranulation, i.e., luminal bleb formation and/or visible loss of granular area (time points $1 \rightarrow 2$ : $\mathrm{WT}=0.55 \pm 0.45$ minutes; $C f t r-\mathrm{KO}=1.77 \pm 0.47 \mathrm{~min}$ utes, $P<0.05$; Figure 2B). Exocytosis by $\mathrm{Cft} r$-KO goblet cells was an abrupt, almost forceful, event that contrasted with the orderly progress of WT exocytosis. Hence, the rate of granule area change from initiation to conclusion of exocytosis was 3 times the exocytotic rate in WT goblet cells (Figure 2D, exocytosis-minimum). Luminal mucus blebs were only observed on the Cftr-KO goblet cells and formed simultaneously as the granule area decreased to a minimum that was similar in magnitude to that of WT goblet cells (Figure 2, B and C). Cupping of the apical thecal area in Cftr-KO goblet cells was not observed (see also transmission electron microscopy [TEM] in Figure 3E). The Cftr-KO luminal mucus blebs attained a 2D area $\left(208.0 \pm 42.0 \mu \mathrm{m}^{2}\right)$ that was 
A

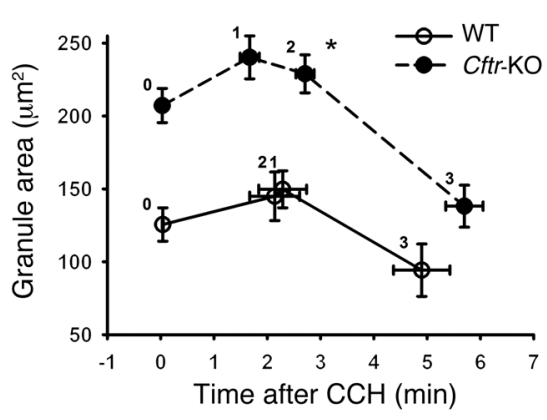

D

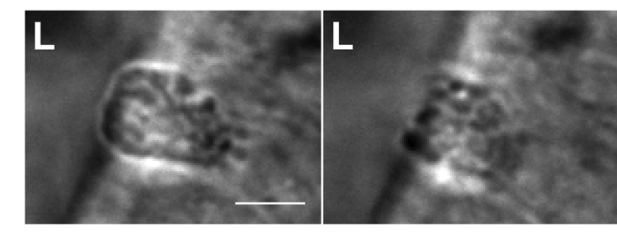

B

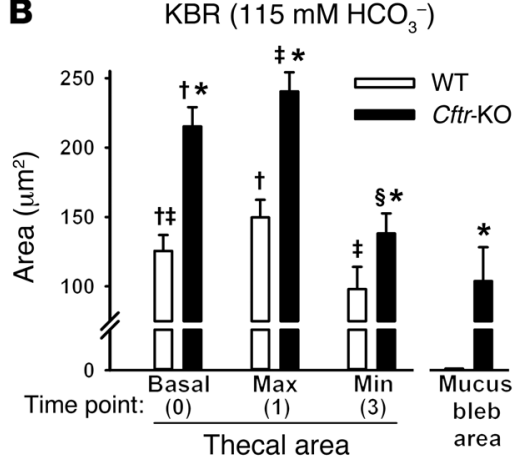

C

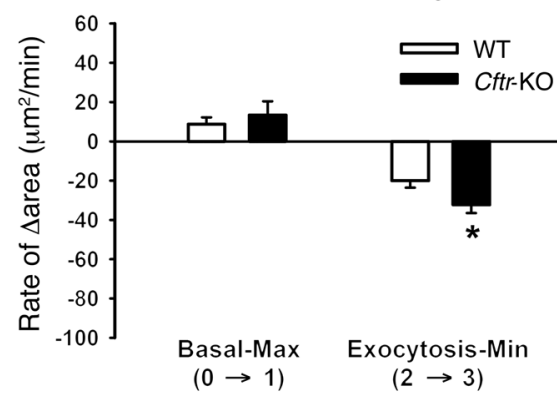

Figure 4. Dynamics of goblet cell exocytosis induced by $100 \mu \mathrm{M} \mathrm{CCH}$ in WT and Cftr-KO enteroids superfused luminally with $115 \mathrm{mM} \mathrm{HCO}_{3}^{-} \mathrm{KBR}^{-}$(A) Dynamics of CCH-stimulated exocytosis. Time points are as defined in Figure $2 .{ }^{*} P<0.05$, time period between $1 \rightarrow 2$ is significantly longer than in WT by $t$ test. (B) Statistical analyses of cross-sectional area of goblet cell granule cluster at basal (time point 0 ), maximum (time point 1 ), and minimum (time point 3). Mucus bleb area is equal to the cross-sectional area of luminal bleb from a perimeter line drawn between the apical membranes of adjacent enterocytes and outlining the mass in the crypt lumen after $\mathrm{CCH}$-induced exocytosis. ${ }^{+,+\$ \$}$ Within group, means with different symbols are statistically different by ANOVA with post-hoc Tukey's test. ${ }^{*} P<0.05$, significantly different from WT by $t$ test. $n=7-13$ goblet cells in enteroids from 4 WT and $C f t r-K O$ sex-matched littermates. (C) Rate of change in granule area between basal and maximum (time points $0 \rightarrow 1$ ) and between exocytosis and minimum (time points $2 \rightarrow 3$ ) after $C$ CH exposure. ${ }^{*} P<0.05$, significantly different from WT by $t$ test. (D) Time-lapse microscopy of luminal bleb formation by $C f t r-K O$ goblet cell superfused with $115 \mathrm{mM} \mathrm{HCO}_{3}{ }^{-} \mathrm{KBR}$. Left panel, enlarged granule cluster 2.92 minutes after $\mathrm{CCH}$ treatment; panel 2, normal-appearing progression of degranulation after CCH treatment; panel 3, appearance of transparent luminal blebs (white arrow) as mucin granules accumulate; panel 4, stationary granular bleb after exocytosis. L, lumen of enteroid. Scale bar: $10 \mu \mathrm{m}$.

approximately 5 -fold greater than the loss of granule area ( $\Delta$ basal to minimum $=-38.6 \pm 9.6 \mu \mathrm{m}^{2}$ ), suggesting a greatly reduced exocytotic expansion of $\mathrm{Cftr}$-KO mucin granules as compared with an expected expansion of 350- to 600-fold (45).

Ectopic granule location in Cftr-KO goblet cells. In the enteroid studies, $\mathrm{CCH}$-induced exocytosis and luminal mucus bleb formation by $C f t r-K O$ goblet cells was often accompanied by the delayed appearance of a similar bleb at the basal aspect of the enteroid (Figure $3 \mathrm{~A}$ and Supplemental Video 2). The translucent appearance of the basal bleb and occasional observations of an apical-to-basal wave of cell distortion before formation of a basal bleb suggested ectopic basolateral exocytosis in the enteroids. However, the epithelial-laminin interface in enteroid culture does not recapitulate basement membrane composition in vivo (46); therefore, studies were performed using WT and Cftr-KO intestine. Freshly excised loops of small intestine were placed in warmed, oxygenated baths $\left(37^{\circ} \mathrm{C}, 95 \% \mathrm{O}_{2}: 5 \% \mathrm{CO}_{2}\right)$ containing $25 \mathrm{mM} \mathrm{HCO}_{3}{ }^{-} \mathrm{KBR}$ with or without $100 \mu \mathrm{M} \mathrm{CCH}$. After 20 minutes, the intestinal loops were collected, fixed, and sectioned for MUC2 IHC, periodic acid-Schiff (PAS) histology, or TEM. As shown in Figure 3B, MUC2 staining of WT goblet cells, whether untreated or $\mathrm{CCH}$ treated, was confined to the goblet cell thecal area, with light staining extending to the apical aspect of the nucleus. Epithelial staining was not observed in the absence of primary MUC2 antibody (Supplemental Figure 2). $\mathrm{CCH}$ treatment resulted in the formation of a MUC2-positive mucus layer on the epithelial surface and reduced granule area in WT goblet cells. In contrast, as shown in Figure 3C, 8.6\% (9/105, $n=6$ sections) of untreated $\mathrm{Cftr}$-KO goblet cells in both villus and crypt compartments exhibited MUC2 staining extending from the apical pole to the basement membrane. In some cases, the basement membrane protruded into the lamina propria. Luminal bleb formation over MUC2-stained cells was often apparent. $\mathrm{CCH}$ treatment increased the proportion of goblet cells showing basal extension of MUC2 staining to $18.2 \%(28 / 209, n=6$ sections). Histologically, PAS-positive granules in some Cftr-KO, but not WT, goblet cells were located at or basal to the level of the cell nucleus (see Supplemental Figure 3).

At the ultrastructural (TEM) level, untreated WT goblet cells had the expected appearance of a granule-filled theca located just apical to the nucleus (Figure 3D, left). Following $\mathrm{CCH}$, most WT goblet cells exhibited cavitation at the apical pole with remaining granules near the apical margin of the nucleus, and rarely, amorphous material was observed near the midregion of the nucleus (Figure 3D, right). In untreated $\mathrm{Cftr}$-KO intestine (Figure 3E, left), goblet cells had features similar to WT goblet cells, but occasional Cftr-KO goblet cells had luminal blebs and amorphous material extending past midnucleus to the basal aspect of the cell (additional examples in Supplemental Figure 4). Following $\mathrm{CCH}$ (Figure 3E, right), Cftr-KO goblet cells commonly had granules/amorphous vacuoles causing displacement or distorting the shape of the nucleus. The amorphous granules/ vacuoles often extended to the basement membrane; however, breach of the basolateral plasmalemma or basement membrane could not be conclusively identified. In contrast to WT goblet 
A

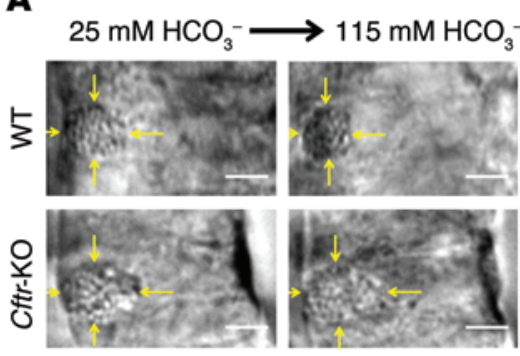

C

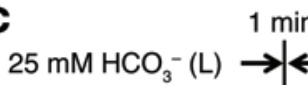

B

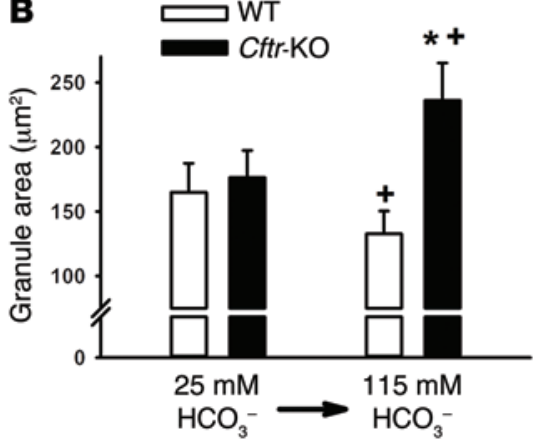

$115 \mathrm{mM} \mathrm{HCO}_{3}^{-}$(L)

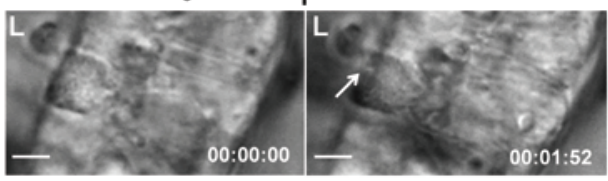

D

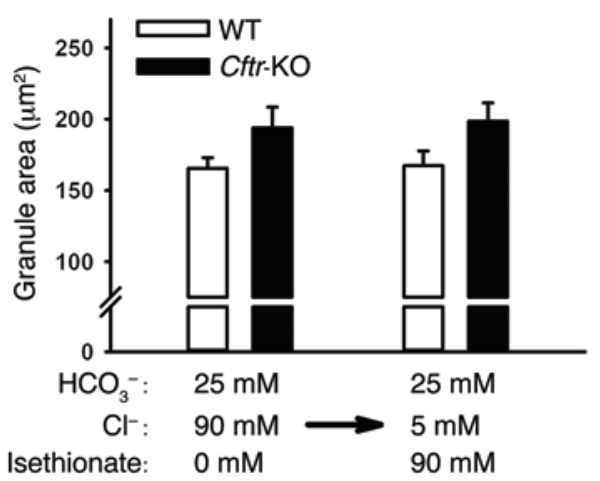

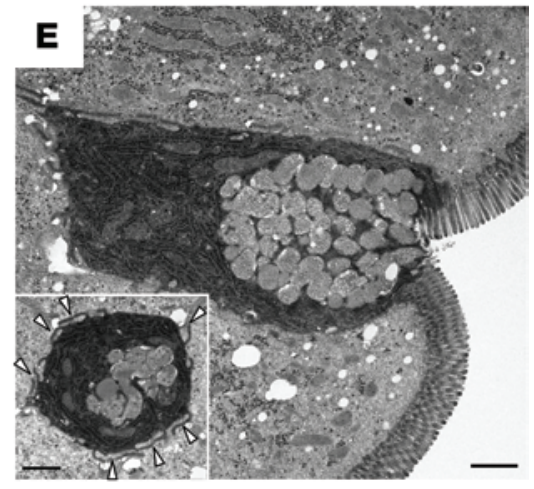

Figure 5. Effect of acutely switching luminal superfusate from $25 \mathrm{mM} \mathrm{HCO}_{3}{ }^{-}$to $115 \mathrm{mM}$ $\mathrm{HCO}_{3}^{-}$KBR on granule cluster area in WT and Cftr-KO goblet cells. (A) Photomicrograph depicting reduced granule area in WT goblet cell and increased granule area in Cftr-KO goblet cell when luminal superfusate is switched from $25 \mathrm{mM} \mathrm{HCO}_{3}{ }^{-}$to $115 \mathrm{mM} \mathrm{HCO}_{3}{ }^{-} \mathrm{KBR}$. Yellow arrows indicate borders of granule cluster. Lumen of crypts at left. Scale bars: $10 \mu \mathrm{m}$. (B) Composite data for granule cluster area before and after switching luminal superfusate from $25 \mathrm{mM} \mathrm{HCO}_{3}^{-}$to $115 \mathrm{mM} \mathrm{HCO}_{3}^{-}$KBR. ${ }^{*} P<0.05$, significantly different from WT by $t$ test; ${ }^{+} P<0.05$, significantly different from $25 \mathrm{mM}$ $\mathrm{HCO}_{3}{ }^{-} \mathrm{KBR}$ by paired $t$ test. $n=6-7$ goblet cells from 3 WT and Cftr-KO sex-matched littermates. (C) Time-lapse videomicroscopy showing WT exocytosis (white arrow) after switching the luminal superfusate from 25 $\mathrm{mM} \mathrm{HCO}_{3}{ }^{-}$KBR to $115 \mathrm{mM} \mathrm{HCO}_{3}{ }^{-} \mathrm{KBR} . \mathrm{L}$, lumen. Scale bars: $10 \mu \mathrm{m}$. (D) Composite data of granule area before and after switching luminal superfusate from $25 \mathrm{mM} \mathrm{HCO}_{3}^{-}$KBR to $25 \mathrm{mM} \mathrm{HCO}_{3}^{-} \mathrm{KBR}$ with isethionate- substituted for $90 \mathrm{mM} \mathrm{Cl}^{-}, n=6-7$ goblet cells from enteroids of $3 \mathrm{WT}$ and $C f t r-K O$ littermate mice. NS by $t$ test and paired $t$ test as in $\mathbf{B}$. (E) TEM of goblet cell in villous epithelium of WT intestine. Note recessed apical membrane of goblet cell. Inset, cross-section at basal half of goblet cell theca showing extensive membrane interdigitation with adjacent enterocytes (white arrowheads). Scale bars: $1 \mu \mathrm{m}$. cells, cavitation at the apical aspect of the granule cluster was not apparent, whereas luminal blebs and/or granule compaction at the apical pole was observed.

Partial correction of abnormal exocytosis in Cftr-KO goblet cells by luminal superfusion with a high bicarbonate concentration. Studies by Gustafsson et al. have shown a positive effect of high luminal $\mathrm{HCO}_{3}{ }^{-}$concentration on the adherence of surface mucus in the $\mathrm{Cftr}$ $\mathrm{KO}$ intestine (9). To determine whether high luminal $\mathrm{HCO}_{3}^{-}$has a beneficial effect on the dynamics of $\mathrm{Cftr}$-KO goblet cell function, enteroids were superfused on the luminal membrane with a KBR solution containing $115 \mathrm{mM} \mathrm{NaHCO}$ gassed with $5 \% \mathrm{CO}_{2}$, which has an effective $\mathrm{HCO}_{3}$ concentration of approximately $100 \mathrm{mM}$ (9).

As shown in Figure 4, A and B, luminal superfusion with $115 \mathrm{mM} \mathrm{HCO}_{3}^{-}$before $\mathrm{CCH}$ addition altered the basal granule area in WT and Cftr-KO goblet cells in opposite ways (compare with Figure 2). In WT goblet cells, basal granule area was less than in cells superfused with $25 \mathrm{mM} \mathrm{HCO}_{3}^{-}$, although the change did not attain statistical significance in this cohort (115 $\mathrm{mM} \mathrm{HCO}_{3}^{-}: 125.6$ $\pm 11.4 \mu^{2}$ vs. $25 \mathrm{mM} \mathrm{HCO}_{3}^{-}: 144.6 \pm 21.5 \mu \mathrm{m}^{2}$, NS). Spontaneous exocytosis by WT goblet cells was occasionally apparent in this experiment and had not been observed during $25 \mathrm{mM} \mathrm{HCO}_{3}$ superfusion (see below). In contrast to WT, basal granule area in Cftr-KO goblet cells after $115 \mathrm{mM} \mathrm{HCO}_{3}{ }^{-}$superfusion was dramatically increased as compared with WT (Figure 4, A and B) and CftrKO goblet cells superfused with $25 \mathrm{mM} \mathrm{HCO}_{3}^{-}\left(115 \mathrm{mM} \mathrm{HCO}_{3}^{-}\right.$: $207.2 \pm 11.7 \mu \mathrm{m}^{2}$ vs. $\left.25 \mathrm{mM} \mathrm{HCO}_{3}^{-}: 146.1 \pm 11.7 \mu \mathrm{m}^{2}, P<0.05\right)$.
Luminal superfusion with $115 \mathrm{mM} \mathrm{HCO}_{3}^{-}$also altered the dynamics of exocytosis by the Cftr-KO goblet cells. Granule area in both WT and Cftr-KO goblet cells increased slightly at the same rate after $\mathrm{CCH}$ exposure (Figure $4 \mathrm{C}$ ). WT goblet cells began exocytosis at this point, whereas there was still a significant delay before exocytosis by $C f t r-\mathrm{KO}$ goblet cells (time points $1 \rightarrow 2$ : WT $=-0.15 \pm$ 0.41 minutes; $C f t r-\mathrm{KO}=1.04 \pm 0.26$ minutes, $P<0.05$; Figure $4 \mathrm{~A}$ ). Granule area in the $C f t r-K O$ goblet cells decreased more during exocytosis and at a greater rate as compared with WT (Figure 4C, exocytosis-minimum), but remained slightly larger at the completion of exocytosis (minimum, Figure 4, A and B). Most importantly, the percentage of Cftr-KO goblet cells developing a luminal bleb decreased to $25.0 \%$ as compared with $\mathrm{Cftr}$-KO goblet cells superfused with $25 \mathrm{mM} \mathrm{HCO}_{3}^{-}(57.1 \%, P<0.05)$. The cross-sectional area of luminal blebs was also reduced by approximately one-half (compare Figure $2 \mathrm{C}$ and Figure $4 \mathrm{~B}$ ) and appeared more granular and opaque. As shown by stills from a video sequence in Figure 4D (see also Supplemental Video 3), the enlarged Cftr-KO granular area superfused with $115 \mathrm{mM} \mathrm{HCO}_{3}^{-}$and exposed to $\mathrm{CCH}$ began exocytosis in an orderly process similar to that of WT goblet cells. However, as exocytosis proceeded, decondensation of released granules apparently did not keep pace, resulting in the formation of small, transparent luminal blebs and the accumulation of a granular mass at the cell surface.

Luminal superfusion of both WT and Cftr-KO goblet cells with $115 \mathrm{mM} \mathrm{HCO}_{3}{ }^{-}$appeared to mimic the early stages of $\mathrm{CCH}$-induced exocytosis. To more directly evaluate the effect 

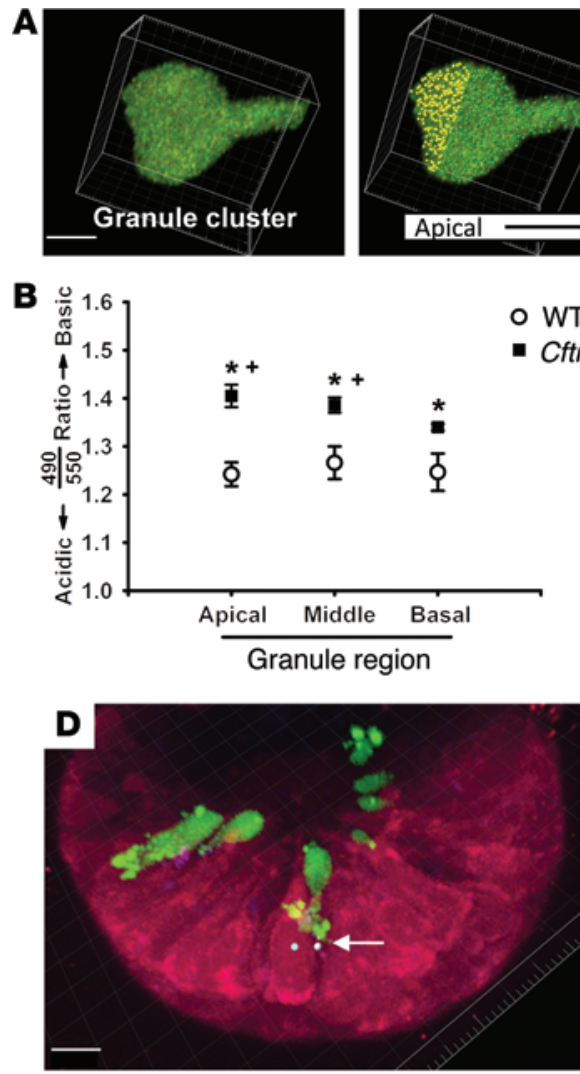
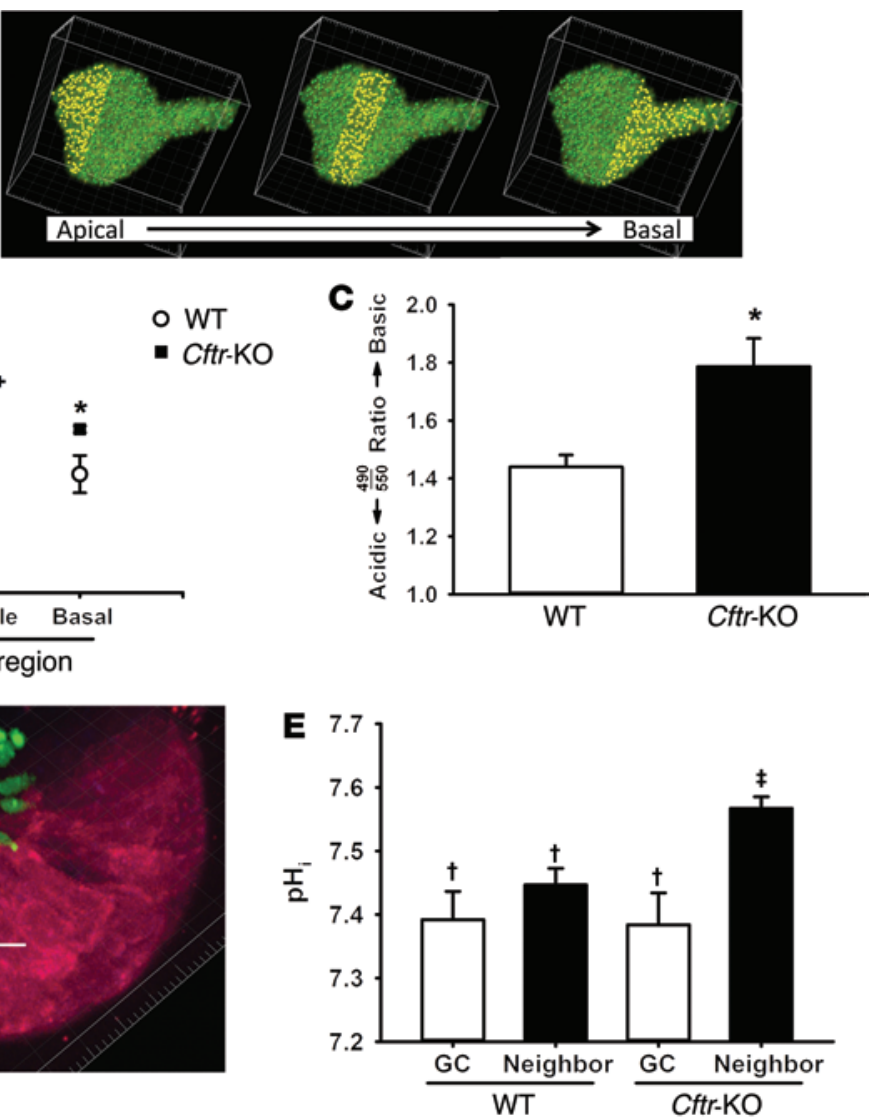

Figure 6. Alkaline mucin granules in goblet cells of $\mathbf{C f t r - K O}$ enteroids. (A) Left panel, LysoSensor-stained granule cluster in a single goblet cell. Right panel, virtual measurement spots (yellow) placed on granules (green) at apical, middle, and basal thirds of granule cluster. Scale bar: $3 \mu \mathrm{m}$. (B) The $490 \lambda / 550 \lambda$ emission ratio of LysoSensor-stained granules at the apical, middle, and basal thirds of granule mass in intact WT and Cftr-KO enteroids. Enteroids were superfused with $25 \mathrm{mM} \mathrm{HCO}_{3}{ }^{-} \mathrm{KBR} .{ }^{*} P<0.05$, significantly different from WT by $t$ test; ${ }^{+} P<0.05$, significantly different from ratio at basal third by repeated-measures ANOVA with post-hoc Bonferroni's test. $n=13-14$ goblet cells in intact enteroids from 6 WT and $C f t r-K O$ sex-matched littermates. (C) The $490 \lambda / 550 \lambda$ emission ratio of LysoSensor-stained granule cluster in goblet cells of bisected WT and Cftr-KO enteroids. ${ }^{*} P<0.05$, significantly different from WT by $t$ test. $n=6$ goblet cells in bisected enteroids from 3 WT and $C f t r-K O$ sex-matched littermate pairs. (D) Method for $p H$. measurement using SNARF-5F (red) and quinacrine (green) in intact WT and Cftr-KO enteroids. Arrow, virtual measurement spheres placed within the plasmalemma confines of 3D constructed goblet cells and adjacent enterocytes. Scale bar: $15 \mu \mathrm{m}$. (E) Mean pH of goblet cells (GC) and adjacent enterocytes (neighbor) in intact WT and Cftr-KO enteroids. ${ }^{\dagger}{ }^{\star \neq}$ Within group, means with different symbols are statistically different by ANOVA with post-hoc Tukey's test, $P<0.05 . n=14-17$ goblet cells in enteroids from 6 WT and Cftr-KO sex-matched littermates.

of $115 \mathrm{mM} \mathrm{HCO}_{3}^{-}$, the luminal superfusate for WT and $\mathrm{Cftr}-\mathrm{KO}$ enteroids was acutely switched from $25 \mathrm{mM} \mathrm{HCO}_{3}^{-}$to $115 \mathrm{mM}$ $\mathrm{HCO}_{3}^{-} \mathrm{KBR}$ solution (Figure 5, A and $\mathrm{B}$ ). As expected, switching to the higher luminal $\mathrm{HCO}_{3}{ }^{-}$concentration reduced granule area in the WT goblet cells $(-19.6 \%)$ and increased granule area in Cftr-KO goblet cells $(+33.3 \%)$. The decrease in granule area of WT goblet cells was consistent with a moderate induction of exocytosis. Spontaneous exocytosis was visibly appreciable in some WT goblet cells (Figure 5C). The paucity of the WT exocytotic events and extended recording times confounded a direct measurement of WT exocytotic rate, but the rate of change in granule area after switching to $115 \mathrm{mM} \mathrm{HCO}_{3}^{-} \mathrm{KBR}$ was $-5.6 \pm$ $1.9 \mu \mathrm{m}^{2} / \mathrm{min}(P<0.05$ vs. $0 ; n=6-7)$. Although the change in granule area as a measure of exocytosis may be affected by unappreciated changes in granule or cell hydration, the longitudinal axis of the granule cluster in WT goblet cells decreased, whereas the transverse axis did not change ( $\Delta$ long axis $=-2.3 \pm$ $0.4 \mu \mathrm{m}, P<0.05 ; \Delta$ tranverse axis $=-0.5 \pm 0.3 \mu \mathrm{m}, \mathrm{NS})$, which is consistent with changes in granule cluster morphology in human colonic goblet cells undergoing stimulated exocytosis as compared with nonresponding goblet cells (47). The composition of the $115 \mathrm{mM} \mathrm{HCO}_{3}^{-} \mathrm{KBR}$, as compared with $25 \mathrm{mM} \mathrm{HCO}_{3}^{-}$ $\mathrm{KBR}$, involved substitution of $90 \mathrm{mM} \mathrm{HCO}_{3}^{-}$for $90 \mathrm{mM} \mathrm{Cl}^{-}$. To determine whether decreased luminal $\mathrm{Cl}^{-}$concentration contributed to the observed effects, the luminal superfusate for WT and $\mathrm{Cftr}$-KO enteroids was acutely switched from $25 \mathrm{mM} \mathrm{HCO}_{3}^{-}$ $\mathrm{KBR}$ to $25 \mathrm{mM} \mathrm{HCO}_{3}^{-} \mathrm{KBR}$ in which $90 \mathrm{mM} \mathrm{Cl}^{-}$was replaced with the impermeant anion isethionate- ${ }^{-}$As shown in Figure 5D, the switch to isethionate KBR did not affect the granule area of either WT or Cftr-KO goblet cells. The effects of high luminal $\mathrm{HCO}_{3}{ }^{-}$concentrations on goblet cell function may have physiological relevance. It is possible that high $\mathrm{HCO}_{3}{ }^{-}$concentrations are achieved by $\mathrm{Cft}$-dependent transport at the luminal surface of goblet cells in vivo, especially when confined by an unstirred layer within the crypt or the recessed apical membrane of goblet cells on villi (see Figure 5E and refs. 48, 49). 
Mucin granules in Cftr-KO goblet cells have an alkaline $\mathrm{pH}$ relative to WT. Mucingranule $\mathrm{pH}$ reflects the end point of the acidic secretory pathway and influences granule organization, mucin packaging, and granular $\mathrm{Ca}^{2+}$ signaling/polyionic composition (8, 23-25). In other secretory cells, granule $\mathrm{pH}$ is known to significantly alter the rate of exocytosis (26). Since CFTR plays a significant role in intestinal epithelial pH physiology $(35,50)$, we asked whether mucin granule $\mathrm{pH}$ differed in Cftr-KO goblet cells. Using LysoSensor, a fluorescent ratiometric $\mathrm{pH}$ indicator $(\mathrm{pH}$ range $=3.5-6.0$ ), and Imaris $3 \mathrm{D}$ imaging, the mucin granule $\mathrm{pH}$ was compared between WT and Cftr-KO goblet cells at the apical, middle, and basal thirds of the granule cluster (Figure 6A). As shown in Figure 6B, the granule $\mathrm{pH}$ in the $C f t r-\mathrm{KO}$ goblet cell granule cluster was significantly alkaline at each level as compared with WT. An apical-to-basal gradient with decreasing $\mathrm{pH}$ was observed in the Cftr-KO but not WT granule cluster. As an independent validation of alkaline granule $\mathrm{pH}$ in Cftr-KO goblet cells, the intensity of quinacrine staining of mucin granules from our studies of intracellular $\mathrm{pH}\left(\mathrm{pH}_{\mathrm{i}}\right.$, see below) was compared between enteroids from WT and Cftr-KO sex-matched littermates. Quinacrine is a fluorescent weak base that accumulates into acidic secretory granules, including mucin granules $(26,35)$; it was used in the $\mathrm{pH}_{\mathrm{i}}$ studies to identify goblet cells. Since quinacrine uptake and intensity are reduced by alkalizing secretory granule $\mathrm{pH}$ (26), it would be predicted that quinacrine intensity is less in alkaline Cftr-KO mucin granules. These measurements revealed that intensity of quinacrine-loaded granule clusters in Cftr-KO goblet cells was reduced relative to WT in all pairs by $24.8 \% \pm 0.1 \%$ $(P<0.05,64$ and 78 goblet cells, respectively, from $n=6 \mathrm{WT}$ and Cftr-KO littermate pairs). To confirm that LysoSensor was sensitive to $\mathrm{pH}$ changes in the granules, enteroids were treated with bafilomycin A1 (10 nM, 4 hours) to inhibit the V-ATPase of secretory granule membranes $(24,51)$. Bafilomycin A1 significantly increased granule $\mathrm{pH}$ in WT goblet cells, but was without effect on Cftr-KO granules $(490 \lambda / 550 \lambda$ ratio: $\mathrm{WT}$ vehicle $=1.30 \pm 0.05$; WT bafilomy$\operatorname{cin} \mathrm{A} 1=1.52 \pm 0.03, P<0.05 ; C f t r-\mathrm{KO}$ vehicle $=1.49 \pm 0.05 ; C f t r-\mathrm{KO}$ bafilomycin $\mathrm{A} 1=1.48 \pm 0.03, \mathrm{NS} ; n=3$ ). Acute treatment with CFTR inhibitor-172 alkalizes crypt epithelial $\mathrm{pH}_{\mathrm{i}}$ in WT enteroids (35). To evaluate whether mucin granule $\mathrm{pH}$ is similarly affected, granule $\mathrm{pH}$ was measured in WT enteroids after a 1-hour treatment with 25 $\mu \mathrm{M}$ CFTR inhibitor-172. However, mucin granule $490 \lambda / 550 \lambda$ ratio was unaltered as compared with that in WT goblet cells treated with DMSO vehicle (CFTR inhibitor-172:1.34 \pm 0.11; DMSO: $1.32 \pm 0.08$, $n=7-9$ goblet cells from 3 WT mice).

Since granule $\mathrm{pH}$ measurements were performed on intact WT and Cftr-KO enteroids, differences in the intraluminal milieu ( $\mathrm{pH}$, ionic content) of the enteroids may have altered granule $\mathrm{pH}$ between the 2 groups. To address this, granule $\mathrm{pH}$ was measured in enteroids that had been bisected to allow the goblet cells luminal membrane exposure to KBR for 30 to 60 minutes prior to granule $\mathrm{pH}$ measurement (Figure 6C). Although the granule $490 \lambda / 550 \lambda$ ratio was increased in both WT and Cftr-KO goblet cells, the $C f t r-K O$ granules remained alkaline relative to WT. The greater $490 \lambda / 550 \lambda$ ratio in this experiment may indicate that intact enteroids normally have acidic luminal content, but this should be interpreted cautiously since the enteroids were provided fresh media after bisection that may not have fully equilibrated with $5 \% \mathrm{CO}_{2}$ tension.
Basal $\mathrm{pH}_{i}$ is normal in Cftr-KO goblet cells, but markedly alkaline in adjacent enterocytes. Previous studies of $C f t r-K O$ enteroids demonstrated that resting $\mathrm{pH}_{\mathrm{i}}$ in crypt epithelial cells was alkaline by approximately $0.2 \mathrm{pH}$ units relative to WT enterocytes (35), raising the question of whether goblet cell $\mathrm{pH}_{\mathrm{i}}$ is normal in Cftr-KO enteroids. To the best of our knowledge, goblet cell $\mathrm{pH}_{\mathrm{i}}$ has not been previously measured in a well-differentiated intestinal epithelium. Virtual measurement spheres within the plasmalemmal confines of goblet cells and their immediately adjacent enterocytes were placed in reconstructed 3D images from confocal $1-\mu \mathrm{m}$ slice images of enteroid crypts loaded with quinacrine (to identify the goblet cells) and the pH-sensitive dye SNARF-5F (Figure 6D). Measurements were confined to goblet cells and adjacent enterocytes above the +4 cell position, i.e., inclusive of the transitamplifying zone. As shown in Figure 6E, goblet cell $\mathrm{pH}_{\mathrm{i}}$ in $\mathrm{WT}$ and Cftr-KO enteroids was almost identical. However, in the Cftr-KO enteroids, the $\mathrm{pH}_{\mathrm{i}}$ of adjacent enterocytes was significantly more alkaline than the goblet cell.

\section{Discussion}

Real-time functional dynamics of goblet cell exocytosis in the small intestine have largely gone unexplored, in part due to the relative inaccessibility of goblet cells in the native intestine and past difficulties with primary culture of a well-differentiated intestinal epithelium. Owing to recent advances in intestinal organoid culture (36) and accurate recapitulation of $\mathrm{CF}$ intestinal disease in $\mathrm{CF}$ mouse models, enteroids from WT and Cftr-KO mice enabled visual access from the apical to basal poles of goblet cells surrounded by absorptive enterocytes in situ. The enteroid model was used to determine whether or not goblet cells function normally when the Cftr-KO intestinal epithelium is isolated from the abnormal CF intestinal environment. We found that goblet cells in Cftr-KO enteroids exhibited alterations in exocytotic dynamics, mucus retention, ectopic granule location, and differences in mucin granule $\mathrm{pH}$. Thus, orderly goblet cell exocytosis is an intestinal epithelial-autonomous function of CFTR. In the absence of CFTR, goblet cell dysfunction likely contributes to the pathology of mucoviscidosis in CF intestinal disease. In contrast to goblet cell function, the phenomenon of goblet cell hyperplasia in the CF intestine is likely a consequence of the altered intestinal environment (dysbiosis, inflammation), since goblet cell numbers in $\mathrm{Cft} r$-KO enteroids were not found to differ from those in WT enteroids (52).

Our data indicate that $\mathrm{CCH}$-stimulated exocytosis by the Cftr$\mathrm{KO}$ goblet cell is characterized by an initial, robust increase in the volume of the granule cluster, as indexed by granule area, which is maintained for a finite period before initiation of exocytosis. Studies of WT goblet cells showed that granule volume also tended to increase initially, but the change was apparently countered by coincident onset of exocytosis and granule loss. Our 2D area measurements of the granule cluster as an index of volume may be confounded by granule reorganization or changes in epithelial cell volume $(35,53)$. However, direct observation of individual enlarging mucin granules within the Cftr-KO goblet cell is consistent with partial granule decondensation as a contributor to increased granular area. The subsequent exocytotic expulsion of a partially decondensated mucus bleb supports this notion. Moreover, during the early stages of $\mathrm{CCH}$ stimulation, the enlarging $\mathrm{Cftr}-\mathrm{KO}$ 
cluster remained granular in appearance (i.e., not a mass of coagulated mucus) and the increased granule area occurred without a change in cell height, an index of cell volume (44). If exposure to a high luminal $\mathrm{HCO}_{3}{ }^{-}$concentration can also be regarded as a stimulus of exocytosis, then "swelling" of the granule cluster prior to exocytosis appears to be a consistent feature of stimulated CftrKO goblet cells. Preexocytotic granule swelling and delayed exocytosis are consistent with the slow rate of swelling and diffusivity of mucin granules released by $\mathrm{Cft}$-KO gallbladder columnar cells (54). Further studies will be necessary to determine whether this abnormality results from a defect intrinsic to the stored granule (e.g., improper processing, imbalance in $\mathrm{Ca}^{2+}$ shielding), an alteration in granule membrane electrolyte transport, or a disruption of secretory pore formation in the Cftr-KO goblet cell.

The increased rate of exocytosis during formation of the luminal mucus bleb and ectopic granule location may be a related characteristic of $C f t r-K O$ goblet cells. In the Cftr-KO enteroids, goblet cell exocytosis was typically observed as a forceful event. Since exocytosis is mediated by $\mathrm{Ca}^{2+}{ }_{\mathrm{i}}$-dependent processes acting on contractile elements $(55,56)$, it is significant that past studies have found exaggerated agonist-induced $\mathrm{Ca}^{2+}{ }_{\mathrm{i}}$ mobilization and plasmalemmal $\mathrm{Ca}^{2+}$ influx in CF epithelia that may apply to goblet cells (57-61). It was also observed that luminal bleb formation was sometimes followed by ectopic release of mucus to the basolateral side of the epithelium in Cftr-KO enteroids. This phenomenon prompted a search for ectopic goblet cell exocytosis in native Cftr-KO intestine. Although ectopic exocytosis could not be confirmed, we found that $10 \%$ to $20 \%$ of $C f t r-K O$ goblet cells exhibited ectopic intracellular granule location. Electron microscopy and immunohistochemical and histological imaging of these Cftr-KO goblet cells revealed disruption of cellular morphology, with mucin granules reaching the basal membrane of the cell, suggesting retrograde intracellular granule movement during stimulated exocytosis. Though speculative at this point, the secretory contractions in Cftr-KO goblet cells as luminal mucus bleb forms may force mucin granules toward the basal membrane if the pathway is less resistant. One potential route for retrograde granule movement is goblet cell-associated antigen passageways (GAPs) (62). GAPs normally provide a means for presentation of luminal antigen to submucosal dendritic cells. Together with damage to the goblet cell, disruption of GAPs in this fraction of Cftr-KO goblet cells would likely have immunological consequences and possibly contribute to small bowel inflammation in CF patients and CF mice $(32,42,43)$.

A high luminal $\mathrm{HCO}_{3}{ }^{-}$concentration improved goblet cell exocytosis in Cftr-KO enteroids and induced a low rate of spontaneous exocytosis by WT goblet cells. For Cftr-KO goblet cells, a luminal $115 \mathrm{mM} \mathrm{HCO}_{3}^{-}$concentration increased granule decondensation and reduced luminal mucus bleb formation. Since CFTR-dependent $\mathrm{HCO}_{3}^{-}$secretion is often coincident with physiological mucus secretion (7), these findings indicate that the loss of CFTR-dependent $\mathrm{HCO}_{3}^{-}$secretion by adjacent enterocytes and perhaps across the granule membrane (22) is an important contributor to the pathogenesis of mucoviscidosis. CFTR-dependent $\mathrm{HCO}_{3}^{-}$transport can attain nearly isotonic $(150 \mathrm{mM}) \mathrm{NaHCO}_{3}$ concentrations in pancreatic juice (63). Although the local concentration of $\mathrm{HCO}_{3}{ }^{-}$at the luminal surface of CFTR-competent enterocytes is not known, it is conceivable that high concentrations are achieved within the restricted space of the crypt or in goblet cell recesses on villi. Thus, proper mucin unfolding and the access to enzyme activity would be available for the subsequent release of mucus from the mucosal surface (10). For WT goblet cells, $115 \mathrm{mM} \mathrm{HCO}_{3}^{-}$luminal superfusion induced a moderate rate of exocytosis. Although observation of spontaneous exocytosis was rare, parameters consistently indicating WT goblet cell exocytosis were decreased granular area and morphological changes in the granule cluster indicative of exocytosis (47). Further, $115 \mathrm{mM}$ luminal $\mathrm{HCO}_{3}{ }^{-}$greatly increased granule area in the $C f t r-K O$ goblet cell, which was reminiscent of the early stages of $\mathrm{CCH}$ stimulation. Given the deficits of $\mathrm{HCO}_{3}{ }^{-}$secretion in the Cftr-KO intestine $(50,64,65)$, losing local $\mathrm{HCO}_{3}^{-}$stimulation may contribute to goblet cell enlargement with stored granules, which is often noted in histological sections of CF epithelia. Despite the positive effects of $115 \mathrm{mM} \mathrm{HCO}_{3}^{-}$luminal superfusion, goblet cell dysfunction was still apparent in the Cftr-KO enteroids. After $\mathrm{CCH}$, the initial "swelling" of the granule cluster did not fully normalize after exocytosis and, more importantly, luminal mucus blebs formed on approximately $25 \%$ of the goblet cells. The granular appearance of the luminal blebs in this case, as shown in Supplemental Video 3, may be evidence of an exuberant exocytotic rate that exceeds the capacity for granule decondensation.

An unexpected finding was that mucin granules within Cftr-KO goblet cells are alkaline relative to WT. $C$ ftr-KO goblet cell $\mathrm{pH}_{\mathrm{i}}$ was normal, indicating that goblet cell $\mathrm{pH}_{\mathrm{i}}$ is not regulated by plasmalemmal CFTR as it is in adjacent enterocytes. However, the granule $\mathrm{pH}$ data raise the possibility that finite amounts of CFTR are present in the secretory pathway/mucin granule membrane and play a role in granule acidification. Some studies strongly dispute the contribution of CFTR to organellar acidification, but others find that CFTR provides a counter-anion permeability that facilitates V-ATPase activity (16-21). Estimates that minimal CFTR activity is required in the secretory pathway (66) are supported by studies showing that low-level transfection with recombinant CFTR corrects abnormal mucin sulfation without significantly increasing cAMP-stimulated $\mathrm{Cl}^{-}$permeability in CF airway epithelium (67). Further, studies have shown colocalization of CFTR and mucins within gallbladder columnar cells (11), and more recently, studies of mucin granules isolated from human airway epithelium show that CFTR immunolocalizes with MUC5AC and that a CFTRdependent $\mathrm{Cl}^{-}$conductance enhances granule acidification (22). Consistent with the latter report, we found that a low concentration of bafilomycin A1 alkalized mucin granules in WT but not Cftr-KO goblet cells, suggesting a deficit of V-ATPase activity in CF. A second possibility is that mucin granule $\mathrm{pH}$ is indirectly regulated by CFTR via intercellular communication with neighboring enterocytes. Little is known about gap junction-connexin communications between goblet cells and adjacent enterocytes, but extensive interdigitation of the plasma membranes exists at the level of the theca with neighboring alkaline Cftr-KO enterocytes (see Figure $5 \mathrm{E}$, inset). Gap junction-connexin communication provides an ionic conductance in other secretory cells (68). Moreover, gap junctional conductance is increased by an alkaline $\mathrm{pH}_{\mathrm{i}}(69)$ and there is evidence of defective regulation in CF epithelium (70). Thus, the possibility is raised that gap junctional communication at the level of the theca may provide $\mathrm{HCO}_{3}{ }^{-}$availability or, conversely, a proton sink that affects granule $\mathrm{pH}$ in the $\mathrm{Cftr}-\mathrm{KO}$ goblet cell. 
The alkaline $\mathrm{pH}$ of $\mathrm{Cftr}$-KO mucin granules is predicted to have consequences regarding goblet cell exocytosis and a potential contribution to mucoviscidosis. It is not clear whether the degree of alkalinity in the Cftr-KO granules is sufficient to alter the $\mathrm{pH}-$ sensitive steps of mucin multimerization and N-terminal cleavage. In vitro, multimerization and N-terminal cleavage of MUC2 occur at up to $\mathrm{pH}$ 6.0-6.2 $(8,23)$, so the $\mathrm{pH}$ difference between WT and $\mathrm{Cft}$-KO granules in a more acidic range may have little effect. More consistent with our observations, it is known that an alkaline granule $\mathrm{pH}$ slows or even inhibits exocytosis in secretory cells. In chromaffin granule membranes, disassociation of the multimeric V0 subunit from the V1 subunit of the V-ATPase is an inverse linear function of intragranular $\mathrm{pH}$, and the disassociated $\mathrm{VO}$ subunit is important to formation of the fusion pore (71). An alkaline granule $\mathrm{pH}$ also reduces granule $\mathrm{Ca}^{2+}$ signaling by mucin granules, which may delay exocytosis and diminish feedback to the goblet cell of the exocytotic event (25). However, it is the effect of an alkaline secretory path on the polyionic composition of mucins that may cause the greatest disturbance to exocytosis by altering the Donnan equilibrium process of decondensation. In solutions of identical ionic composition, Verdugo demonstrated that extracellular $\mathrm{Ca}^{2+}$ inhibition of the swelling of CF mucin granules was about 5 times greater relative to mucin granules from normal human airway goblet cells, thereby indicating increased mucin- $\mathrm{Ca}^{2+}$ affinity in $\mathrm{CF}$ granules (72). Consonant with this, electron microprobe analysis has found higher $\mathrm{Ca}^{2+}$ content in $\mathrm{CF}$ airway secretory granules (73). An alkaline $\mathrm{pH}$ in $\mathrm{Cftr}$-KO granules and the secretory pathway would be predicted to increase mucin- $\mathrm{Ca}^{2+}$ affinity by mucin deprotonation $(74,75)$ and increased mucin sulfation $(67,76)$. Mucus sulfation is considered to be a primary defect in CF that has been associated with a favorable $\mathrm{pH}$ optima of sulfotransferases in an alkaline secretory pathway (77). Increased mucin- $\mathrm{Ca}^{2+}$ affinity would negatively affect $\mathrm{Na}^{+} / \mathrm{Ca}^{2+}$ exchange and polymer gel-phase transition after formation of the fusion pore $(72,78)$. Speculation that this represents a $\mathrm{CF}$ mucin defect beyond $\mathrm{Ca}^{2+}-\mathrm{HCO}_{3}{ }^{-}$chelation (78) is consistent with our observation that exocytotic dysfunction persists in Cftr-KO goblet cells when superfused directly on the luminal membrane with $115 \mathrm{mM} \mathrm{HCO}_{3}^{-} \mathrm{KBR}$.

Goblet cell dysfunction may contribute to the pathology of mucoviscidosis in human intestinal CF disease. We found that, in comparison with WT, intracellular granule expansion, intracellular ectopic granule location, and exocytosis of partially decondensated mucus characterized Cftr-KO goblet cells. The observed anchoring of partially decondensated mucus to the goblet cell greatly increased the surface area of mucosal contact in the formation of obstructing impactions (79-81), sequestered secreted antimicrobials/trefoil factors (2), and impeded nutrient access (82) at the intestinal epithelium. Extrapolated to the CF airways, mucus retention by goblet cells may be the cellular basis for impaired mucus detachment from submucosal gland ducts that is responsible for deficient mucociliary transport in the CF pig model (30). In addition to mucus retention, mislocalization of mucin granules within the goblet cell may negatively affect luminal antigen presentation to submucosal dendritic cells and contribute to the inflammatory component of CF intestinal disease (62). Identifying and correcting the process of mucin granule alkalization will shed light on the early stages in the pathogenesis of mucoviscido- sis. From an immediate perspective, our data show that provision of a high concentration of $\mathrm{HCO}_{3}^{-}$to the mucosal surface greatly improves goblet cell dysfunction. Therapeutic use of $\mathrm{HCO}_{3}^{-}-$ containing solutions for inhalation therapy of CF lung disease has been advocated (9), but ingestion of $\mathrm{HCO}_{3}^{-}$-containing medications might also be considered for the treatment of distal intestinal-obstruction syndrome (DIOS) and constipation in CF patients.

\section{Methods}

Animals. Mice with gene-targeted disruption of the murine homolog of Cftr (Abcc7, CftrtmiUnc, Cftr-KO) and sex-matched $\mathrm{Cftr}^{+/+}$or Cftr ${ }^{+/-}$(WT) littermates were used (80). Mice were routinely outbred to Black Swiss (Taconic) at generational intervals. Resulting F1 heterozygotes were crossed to generate $\mathrm{F} 2 \mathrm{offspring}$ for experimentation. The mutant mice were identified using a PCR-based analysis of tail-snip DNA, as previously described (33). All mice were maintained ad libitum on standard laboratory chow (Formulab 5008, rodent chow; Ralston Purina) and distilled water containing Colyte (Schwartz Pharma) laxative to avoid intestinal obstruction in the Cftr-KO mice (33). Mice were housed individually in a temperature- and light-controlled room $\left(22-26^{\circ} \mathrm{C}\right.$; 12-hour light:12-hour dark cycle) in the Association for Assessment and Accreditation of Laboratory Animal Care-accredited animal facility at the Dalton Cardiovascular Research Center, University of Missouri.

Enteroid culture. The enteroid culture method has previously been described in detail (35). Gel cultures were overlaid with Ham's F-12 medium containing $5 \% \mathrm{FBS}, 50 \mu \mathrm{g} / \mathrm{ml}$ gentamicin, $125 \mathrm{ng} / \mathrm{ml}$ R-Spondin1, $25 \mathrm{ng} / \mathrm{ml} \mathrm{noggin}$, and $12.5 \mathrm{ng} / \mathrm{ml}$ epidermal growth factor. Medium was changed every 3 days. Primary enteroids were passaged at 7 to 10 days after isolation using Cell Recovery solution (BD Biosciences).

Histology, TEM, and IHC. Freshly excised small intestine was placed in a bath of $\mathrm{KBR}$ with or without $100 \mu \mathrm{M} \mathrm{CCH}$ warmed to $37^{\circ} \mathrm{C}$ and gassed with $95 \%$ oxygen:5\% $\mathrm{CO}_{2}$ (pH 7.4) for 20 minutes. As described for histological sections (35), intestine was fixed in $4 \%$ paraformaldehyde overnight, embedded in paraffin, and sectioned $(5 \mu \mathrm{m})$ for PAS staining. As described previously for TEM (2), sections were fixed in a $2.5 \%$ glutaraldehyde- $2.0 \%$ paraformaldehyde solution, postfixed in $1 \%$ osmium tetroxide/1\% uranyl acetate, and embedded in Epon-araldite (Electron Microscopy Sciences). Thin sections were transferred to 200mesh copper grids before staining with uranyl acetate and lead citrate. Sections were viewed with a JEOL $1400 \mathrm{TEM}$ at $80 \mathrm{kV}$ accelerating voltage. For MUC2 IHC, tissue was fixed using 4\% paraformaldehyde followed by $30 \%$ sucrose in PBS, embedded in OCT, and frozen on dry ice. Sections $(5 \mu \mathrm{m})$ were placed on positively charged slides, permeabilized with $0.1 \%$ Igepal, and incubated for 2 hours at room temperature (RT) with rabbit anti-human MUC2 (H-300) primary antibody (Santa Cruz Biotechnology Inc., no. sc-15334) diluted 1:50. Sections were treated with $3 \%$ hydrogen peroxide followed by a 1-hour incubation at RT with a 1:500 dilution of goat anti-rabbit IgG-HRP-conjugated secondary antibody (Santa Cruz Biotechnology Inc., no. sc-2004). Sections were counterstained for 20 seconds with a 1:10 dilution of Mayer's Hematoxylin (Dako). Sections incubated without primary antibody were used to assess nonspecific labeling. Images were acquired using an Olympus IX73 microscope and ImageJ software (http://imagej.nih.gov/ij/).

Enteroid superfusion and exocytosis videomicroscopy. Enteroids from WT and Cftr-KO littermates were plated in Matrigel on chambered glass microscope slides (BD Biosciences) and cultured for 4 days. Enteroids were punctured on 1 side (opposite to bath flow) using 
a 30-gauge needle under stereomicroscopy. The microscope slide was fitted with a polycarbonate perfusion chamber (Warner Instruments) for superfusion ( $3 \mathrm{ml} / \mathrm{min}$ ) with a KBR solution containing the following: $115 \mathrm{mM} \mathrm{NaCl}, 25 \mathrm{mM} \mathrm{NaHCO}, 2.4 \mathrm{mM} \mathrm{K}_{2} \mathrm{HPO}_{4}, 0.4 \mathrm{mM}$ $\mathrm{KH}_{2} \mathrm{PO}_{4}, 1.2 \mathrm{mM} \mathrm{CaCl}_{2}, 1.2 \mathrm{mM} \mathrm{MgCl}_{2}$, and $10 \mathrm{mM}$ glucose gassed with

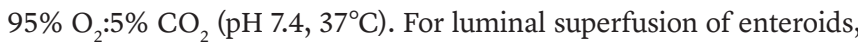
micropipettes were constructed from aluminum silicate glass capillary tubes (1.2 mm OD) pulled on a horizontal puller (P-97 Flaming/ Brown, Sutter Instrument Co.) and beveled to an approximately $30-\mu \mathrm{m}$ tip diameter. Micropipettes were attached to a PicoPump dual syringe pump (Harvard Apparatus) and inserted into the punctured enteroid opposite the bath superfusion flow using a remote-controlled micromanipulator (MW-3, Narishige International) under visual direction using the $\times 10$ water immersion objective of an upright Olympus BX50WI microscope. Enteroids were luminally superfused at 1 to $2 \mu \mathrm{l} / \mathrm{min}$ with KBR. In some experiments, $90 \mathrm{mM} \mathrm{NaCl}$ was replaced equimolar with $\mathrm{NaHCO}_{3}$ or Na Isethionate. Visible evidence of luminal superfusion included flushing of debris from the lumen and slight distension of the enteroid and enteroid crypts (see Figure 2A). Experiments were discarded if (a) visual evidence of luminal superfusion was not apparent, (b) the enteroid moved excessively, or (c) hydraulic rupture of the enteroid epithelium was apparent (overall, $20 \%$ of experiments were discarded). Using a $\times 60$ water immersion objective, 1 to 3 goblet cells were identified morphologically at more than 4 cell positions distal to the crypt base using granule size and granule cluster location at the apical one-third of the cell. The polarity of the granule cluster was not different between WT and Cftr-KO goblet cells based on measurements of the longitudinal axis of the granule cluster as a percentage of the total cell height in untreated enteroids bathed in $25 \mathrm{mM} \mathrm{HCO}_{3}^{-}$ KBR (WT cluster length/cell height: $26.4 \% \pm 1.0 \%$ vs. Cftr-KO cluster length/cell height: $27.4 \% \pm 1.0 \%, n=16-17$ goblet cells from $4 \mathrm{WT}$ and Cftr-KO sex-matched littermates). Paneth cells were identified by larger granules, a centrally positioned granule cluster, and cell location at the crypt base. Aberrantly located Paneth cells and intermediate cells (83) with larger granules and theca were strictly avoided. Single goblet cells were imaged in the longitudinal plane to obtain the maximal granule area continuously throughout the experiment using a remotecontrolled fine-focus wheel. Enteroids were luminally superfused for approximately 5 to 7 minutes before the addition of $100 \mu \mathrm{M} \mathrm{CCH}$ to the (basolateral) superfusate. Images were acquired at 1- or 5-second intervals for approximately 15 minutes using a Sensi-Cam digital camera (Cooke) and Slidebook 5.0 software (Intelligent Imaging Innovations). Postacquisition analysis of granule area or luminal mucus blebs was performed on a frame-by-frame basis by outlining the perimeter of the granule cluster or bleb with a stylus and obtaining the corresponding area using Slidebook software. Granule or bleb area and the first post-CCH exocytotic event with respective times were measured or observed by a designated operator who was blinded to both mouse genotype and treatment. Granule area measurements were collected at 4 time points during the experiment: $\mathrm{O}$ (also designated as basal) was the granule area in the frame immediately prior to $\mathrm{CCH}$ addition to the basolateral superfusate; 1 (also designated as maximum) was maximal granule area obtained in the frames following $\mathrm{CCH}$ exposure; 2 (also designated as exocytosis) was granule area when first visible evidence of exocytosis was observed as a loss of individual granules or a mucus bleb from the granule cluster; 3 (also designated as minimum) was the granule area when granule loss from the granule cluster was no longer observed. The area of mucus accumulated above the goblet cell theca in Cftr-KO enteroids (designated as mucus bleb area) was acquired at the minimum time point by outlining the luminal perimeter of the mucus bleb above a straight line drawn between the apical membranes of enterocytes adjacent to the goblet cell.

Intracellular $\mathrm{pH}$ and granule $\mathrm{pH}$ measurements. The method for measurement of intracellular $\mathrm{pH}$ of enteroid epithelium has been recently described (35). Briefly, enteroids were incubated with the ratiometric fluorescent $\mathrm{pH}_{\mathrm{i}}$ indicator SNARF-5F (Invitrogen, $40 \mu \mathrm{M}, 30$ minutes) and counterstained with quinacrine (Sigma-Aldrich, $1 \mu \mathrm{M}, 15$ minutes) to identify goblet and Paneth cells. SNARF-5F was excited at $514 \lambda$ and images collected at emission wavelengths of $580 \lambda$ and $640 \lambda$; quinacrine was excited at $488 \lambda$ and images collected at emission wavelengths of $500 \lambda-540 \lambda$ using a TCS SP 5 confocal-multiphoton microscope (Leica). For measurement of mucin granule $\mathrm{pH}$, enteroids were loaded with $5 \mu \mathrm{M}$ LysoSensor Yellow/Blue DND-160, a fluorescent ratiometric $\mathrm{pH}$ indicator ( $\mathrm{pH}$ range $=3.5-6.0$, Invitrogen), for 5 minutes before imaging. LysoSensor dye was excited at $360 \lambda$ ( $720 \lambda$ 2-photon), and dual emissions were collected at $490 \lambda$ and $550 \lambda$. $Z$ stacks of $0.25-\mu$ m slices were acquired, and Imaris software (Bitplane) was used for 3D reconstruction of the goblet cell granule cluster and automated placement of virtual measurement spots on the mucin granules (see Figure 6A). The $490 \lambda / 550 \lambda$ emission ratio acquired from measurement spots was averaged either for the entire granule cluster or at the apical, middle, and basal thirds of the granule cluster. Attempts to calibrate the $490 \lambda / 550 \lambda$ ratio of LysoSensor for $\mathrm{pH}$ using ionophores (nigericin, monensin) to clamp organellar $\mathrm{pH}$ (84) induced goblet cell exocytosis within 2 minutes after exposure. Calibration performed at less than 2 minutes after exposure indicated granule $\mathrm{pH}$ within the reported $\mathrm{pH}$ range for LysoSensor (WT: $4.61 \pm 0.05$ vs. Cftr-KO: $4.84 \pm 0.02, n=6$ ), but a steadystate equilibrium at each calibration of $\mathrm{pH}$ could not be achieved. Due to this inaccuracy, the more precise measurement of the $490 \lambda / 550 \lambda$ emission ratio is reported.

Statistics. All values are reported as mean \pm SEM. Data between 2 groups were compared using a 2-tailed Student's $t$ test assuming equal variances between groups. Data from multiple treatment groups were compared using a 1-way ANOVA with a post hoc Tukey's $t$ test. A repeated-measures ANOVA was used for comparisons between different time points in studies of exocytotic dynamics. $P<0.05$ was considered statistically significant.

Study approval. All experiments involving animals were approved by the University of Missouri IACUC.

\section{Acknowledgments}

The authors would like to thank Emily Bradford (University of Kentucky) for helpful advice about IHC. We would also like to acknowledge the assistance of staff at the University of Missouri Electron Microscopy Core and the Dalton Cardiovascular Research Center Live Cell Imaging Core. This work was supported by National Institute of Diabetes and Digestive and Kidney Diseases grant DK48816-14 (to L.L. Clarke) and Cystic Fibrosis Foundation grants CLARKE11G0 (to L.L. Clarke) and LIU13FO (to J. Liu).

Address correspondence to: Lane L. Clarke, 324D Dalton Cardiovascular Research Center, 134 Research Park Dr., University of Missouri, Columbia, Missouri 65211-3300, USA. Phone: 573.882.7049; E-mail: clarkel@missouri.edu. 
1. Collins FS. Cystic fibrosis: molecular biology and therapeutic implications. Science. 1992;256(5058):774-779.

2. Clarke LL, et al. Abnormal Paneth cell granule dissolution and compromised resistance to bacterial colonization in the intestine of $\mathrm{CF}$ mice. Am J Physiol Gastrointest Liver Physiol. 2004;286(6):G1050-G1058.

3. Weiss AA, Babyatsky MW, Ogata S, Chen A, Itzkowitz SH. Expression of MUC2 and MUC3 mRNA in human normal, malignant, and inflammatory intestinal tissues. J Histochem Cytochem. 1996;44(10):1161-1166.

4. Groneberg DA, et al. Expression of MUC5AC and MUC5B mucins in normal and cystic fibrosis lung. Respir Med. 2002;96(2):81-86.

5. Reeves EP, Molloy K, Pohl K, McElvaney NG. Hypertonic saline in treatment of pulmonary disease in cystic fibrosis. ScientificWorldJournal. 2012;2012:465230.

6. Gustafsson PM, Aurora P, Lindblad A. Evaluation of ventilation maldistribution as an early indicator of lung disease in children with cystic fibrosis. Eur Respir J. 2003;22(6):972-979.

7. Garcia MAS, Yang N, Quinton PM. Normal mouse intestinal mucus release requires cystic fibrosis transembrane regulator-dependent bicarbonate secretion. J Clin Invest. 2009;119(9):2613-2622.

8. Ambort D, et al. Calcium and pH-dependent packing and release of the gel-forming MUC2 mucin. Proc Natl Acad Sci U S A. 2012;109(15):5645-5650.

9. Gustafsson JK, et al. Bicarbonate and functional CFTR channel are required for proper mucin secretion and link cystic fibrosis with its mucus phenotype. J Exp Med. 2012;209(7):1263-1272.

10. Schutte A, et al. Microbial-induced meprin $\beta$ cleavage in MUC2 mucin and a functional CFTR channel are required to release anchored small intestinal mucus. Proc Natl Acad Sci U S A. 2014;111(34):12396-12401.

11. Kuver R, Klinkspoor JH, Osborne WRA, Lee SP. Mucous granule exocytosis and CFTR expression in gallbladder epithelium. Glycobiology. 2000;10(2):149-157.

12. Kalin N, Claass A, Sommer M, Puchelle E, Tummler B. DeltaF508 CFTR protein expression in tissues from patients with cystic fibrosis. J Clin Invest. 1999;103(10):1379-1389.

13. Kreda SM, et al. Characterization of wild-type and deltaF508 cystic fibrosis transmembrane regulator in human respiratory epithelia. Mol Biol Cell. 2005;16(5):2154-2167.

14. Mall $\mathrm{M}$, et al. The $\Delta \mathrm{F} 508$ mutation results in loss of CFTR function and mature protein in native human colon. Gastroenterology. 2004;126(1):32-41.

15. Yu K, Lujan R, Marmorstein A, Gabriel SE, Hartzell HC. Bestrophin-2 mediates bicarbonate transport by goblet cells in mouse colon. JClin Invest. 2010;120(5):1722-1735.

16. Barasch J, Kiss B, Prince A, Saiman L, Gruenert D, al-Awqati Q. Defective acidification of intracellular organelles in cystic fibrosis. Nature. 1991;352(6330):70-73.

17. Liu J, et al. Cystic fibrosis transmembrane conductance regulator (CFTR) contributes to reacidification of alkalinized lysosomes in RPE cells. Am J Physiol Cell Physiol. 2012;303(2):C160-C169.

18. Di A, et al. CFTR regulates phagosome acidifica- tion in macrophages and alters bactericidal activity. Nat Cell Biol. 2006;8(9):933-944.

19. Haggie PM, Verkman AS. Unimpaired lysosomal acidification in respiratory epithelial cells in cystic fibrosis. J Biol Chem. 2009;284(12):7681-7686.

20. Van Dyke RW, Root KV, Schreiber JH, Wilson JM Role of CFTR in lysosome acidification. Biochem Biophys Res Commun. 1992;184(1):300-305.

21. Seksek O, Biwersi J, Verkman AS. Evidence against defective trans-Golgi acidification in cystic fibrosis. JBiol Chem. 1996;271(26):15542-15548.

22. LeSimple P, et al. Cystic fibrosis transmembrane conductance regulator is expressed in mucin granules from Calu- 3 and primary human airway epithelial cells. Am J Respir Cell Mol Biol. 2013;49(4):511-516.

23. Lidell ME, Johansson ME, Hansson GC. An autocatalytic cleavage in the $\mathrm{C}$ terminus of the human MUC2 mucin occurs at the low $\mathrm{pH}$ of the late secretory pathway. J Biol Chem. 2003;278(16):13944-13951.

24. Perez-Vilar J, Olsen JC, Chua M, Boucher RC. $\mathrm{pH}$-dependent intraluminal organization of mucin granules in live human mucous/goblet cells. J Biol Chem. 2005;280(17):16858-16881.

25. Chin WC, Quesada I, Nguyen T, Verdugo P. Oscillations of $\mathrm{pH}$ inside the secretory granule control the gain of $\mathrm{Ca}^{2+}$ release for signal transduction in goblet cell exocytosis. Novartis Found Symp. 2002;248:132-141.

26. Camacho M, Machado JD, Montesinos MS, Criado M, Borges R. Intragranular $\mathrm{pH}$ rapidly modulates exocytosis in adrenal chromaffin cells. J Neurochem. 2006;96(2):324-334.

27. Lethem MI, et al. Nucleotide regulation of goblet cells in human airway epithelial explants: Norma exocytosis in cystic fibrosis. Am J Resp Cell Mol. 1993;9(3):315-322.

28. Hays SR, Fahy JV. Characterizing mucous cell remodeling in cystic fibrosis. Am J Respir Crit Care Med. 2006;174(9):1018-1024.

29. Sbarbati A, Bertini M, Catassi C, Gagliardini R, Osculati F. Ultrastructural lesions in the small bowel of patients with cystic fibrosis. Pediatr Res. 1998;43(2):234-239.

30. Hoegger MJ, et al. Cystic fibrosis. Impaired mucus detachment disrupts mucociliary transport in a piglet model of cystic fibrosis. Science. 2014;345(6198):818-822.

31. De Lisle RC, Roach E, Jansson K. Effects of laxative and $\mathrm{N}$-acetylcysteine on mucus accumulation, bacterial load, transit, and inflammation in the cystic fibrosis mouse small intestine. Am J Physiol Gastrointest Liver Physiol. 2007;293(3):G577-G584.

32. Norkina O, Kaur S, Ziemer D, De Lisle RC. Inflammation of the cystic fibrosis mouse small intestine. Am J Physiol Gastrointest Liver Physiol. 2004;286(6):G1032-G1041.

33. Clarke LL, Gawenis LR, Franklin CL, Harline MC. Increased survival of CFTR knockout mice using an oral osmotic laxative. Lab Anim Sci. 1996;46(6):612-618.

34. Grubb BR, Gabriel SE. Intestinal physiology and pathology in gene-targeted mouse models of cystic fibrosis. Am J Physiol Gastrointest Liver Physiol. 1997;273(2):G258-G266.

35. Liu J, Walker NM, Cook MT, Ootani A, Clarke LL. Functional Cftr in crypt epithelium of organotypic enteroid cultures from murine small intestine. $A m$ JPhysiol Cell Physiol. 2012;302(10):C1492-C1503.

36. Sato T, et al. Single Lgr5 stem cells build cryptvillus structures in vitro without a mesenchymal niche. Nature. 2009;459(7244):262-265.

37. Norkina O, Burnett TG, De Lisle RC. Bacterial overgrowth in the cystic fibrosis transmembrane conductance regulator null mouse small intestine. Infect Immun. 2004;72(10):6040-6049.

38. Kaur S, Norkina O, Ziemer D, Samuelson LC De Lisle RC. Acidic duodenal pH alters gene expression in the cystic fibrosis mouse pancreas. Am J Physiol Gastrointest Liver Physiol. 2004;287(2):G480-G490.

39. De Lisle RC, Isom KS, Norkina O, Zeimer D, Kaur S. The CF mouse small intestine exhibits an innate immune response. Gastroenterology. 2003;124(3):A498.

40. Canale-Zambrano JC, Auger ML, Haston CK. Toll-like receptor- 4 genotype influences the survival of cystic fibrosis mice. Am J Physiol Gastrointest Liver Physiol. 2010;299(2):G381-G390.

41. Canale-Zambrano JC, Poffenberger MC, Cory SM, Humes DG, Haston CK. Intestinal phenotype of variable-weight cystic fibrosis knockout mice. Am J Physiol Gastrointest Liver Physiol. 2007;293(1):G222-G229.

42. Raia V, et al. Evidence of chronic inflammation in morphologically normal small intestine of cystic fibrosis patients. Pediatr Res. 2000;47(3):344-350.

43. Smyth RL, Croft NM, O'Hea U, Marshall TG, Ferguson A. Intestinal inflammation in cystic fibrosis. Arch Dis Child. 2000;82(5):394-399.

44. Gawenis LR, et al. cAMP inhibition of murine intestinal $\mathrm{Na}^{+} / \mathrm{H}^{+}$exchange requires CFTRmediated cell shrinkage of villus epithelium. Gastroenterology.2003;125(4):1148-1163.

45. Verdugo P. Mucin exocytosis. Am Rev Respir Dis. 1991;144(3):S33-S37.

46. Beaulieu JF. Extracellular matrix components and integrins in relationship to human intestinal epithelial cell differentiation. Prog Histochem Cytochem. 1997;31(4):1-76.

47. Halm DR, Halm ST. Secretagogue response of goblet cells and columnar cells in human colonic crypts. Am J Physiol Cell Physiol. 2000;278(1):C212-C233.

48. Horiuchi K, et al. Three-dimensional ultrastructure of the brush border glycocalyx in the mouse small intestine: a high resolution scanning electron microscopic study. Arch Histol Cytol. 2005;68(1):51-56.

49. Madara J, Trier J. The functional morphology of the mucosa of the small intestine. In: Johnson L, ed. Physiology Of The Gastrointestinal Tract. 3rd ed. New York, New York, USA: Raven Press; 1994:1577-1622.

50. Simpson JE, Gawenis LR, Walker NM, Boyle KT, Clarke LL. Chloride conductance of CFTR facilitates basal $\mathrm{Cl}^{-} / \mathrm{HCO}^{-}$exchange in the villous epithelium of intact murine duodenum. Am J Physiol Gastrointest Liver Physiol. 2005;288(6):G1241-G1251.

51. Burgoyne RD, Morgan A. Secretory granule exocytosis. Physiol Rev. 2003;83(2):581-632.

52. Liu J, Walker NM, Clarke LL. Abnormal mucus release but not hyperplasia is an intrinsic property of goblet cells in the CF mouse intestine. 
Pediatr Pulmonol. 2011;34(suppl):236.

53. Perez-Vilar J, Mabolo R, McVaugh CT, Bertozzi $\mathrm{CR}$, Boucher RC. Mucin granule intraluminal organization in living mucous/goblet cells. J Biol Chem. 2006;281(8):4844-4855.

54. Kuver R, Wong T, Klinkspoor JH, Lee SP. Absence of CFTR is associated with pleiotropic effects on mucins in mouse gallbladder epithelial cells. Am J Physiol Gastrointest Liver Physiol. 2006;291(6):G1148-G1154.

55. Davis CW Dickey BF. Regulated airway goblet cell mucin secretion. Annu Rev Physiol. 2008;70:487-512.

56. Kreda SM, Davis CW, Rose MC. CFTR, mucins, and mucus obstruction in cystic fibrosis. Cold Spring Harb Perspect Med. 2012;2(9):a009589.

57. Antigny F, Norez C, Becq F, Vandebrouck C. CFTR and Ca signaling in cystic fibrosis. Front Pharmacol. 2011;2:67.

58. Martins JR, et al. F508del-CFTR increases intracellular $\mathrm{Ca}^{2+}$ signaling that causes enhanced calcium-dependent $\mathrm{Cl}^{-}$conductance in cystic fibrosis. Biochim Biophys Acta. 2011;1812(11):1385-1392.

59. Balghi H, et al. Enhanced $\mathrm{Ca}^{2+}$ entry due to Orai1 plasma membrane insertion increases IL-8 secretion by cystic fibrosis airways. FASEB J. 2011;25(12):4274-4291.

60. Ribeiro CMP. The role of intracellular calcium signals in inflammatory responses of polarised cystic fibrosis human airway epithelia. Drugs $R D$. 2006;7(1):17-31.

61. Antigny F, et al. Transient receptor potential canonical channel 6 links $\mathrm{Ca}^{2+}$ mishandling to cystic fibrosis transmembrane conductance regulator channel dysfunction in cystic fibrosis. Am J Respir Cell Mol Biol. 2011;44(1):83-90.

62. McDole JR, et al. Goblet cells deliver luminal antigen to $\mathrm{CD}_{103}{ }^{+}$dendritic cells in the small intestine. Nature. 2012;483(7389):345-349.

63. Gustafsson JK, Ermund A, Johansson MEV, Schütte A, Hansson GC, Sjövall H. An ex vivo method for studying mucus formation, properties, and thickness in human colonic biopsies and mouse small and large intestinal explants. Am J Physiol Gastrointest Liver Physiol. 2012;302(4):G430-G438.

64. Hogan DL, Crombie DL, Isenberg JI, Svendsen P, Schaffalitzky de Muckadell OB, Ainsworth MA. CFTR mediates cAMP- and $\mathrm{Ca}^{2+}$-activated duodenal epithelial $\mathrm{HCO}^{-}$secretion. Am J Physiol Gastrointest Liver Physiol. 1997;272(4):G872-G878.

65. Pratha VS, Hogan DL, Martensson BA, Bernard J, Zhou R, Isenberg JI. Identification of transport abnormalities in duodenal mucosa and duodenal enterocytes from patients with cystic fibrosis. Gastroenterology. 2000;118(6):1051-1060.

66. Barasch J, al-Awqati Q. Defective acidification of the biosynthetic pathway in cystic fibrosis. J Cell Sci Suppl. 1993;17:229-233.

67. Zhang Y, Jiang Q, Dudus L, Yankaskas JR, Engelhardt JF. Vector-specific complementation profiles of two independent primary defects in cystic fibrosis airways. Hum Gene Ther. 1998;9(5):635-648.

68. Michon L, et al. Involvement of gap junctional communication in secretion. Biochim Biophys Acta. 2005;1719(1):82-101.

69. Spray DC, Harris AL, Bennett MV. Gap junctional conductance is a simple and sensitive function of intracellular pH. Science. 1981;211(4483):712-715.

70. Chanson M, Scerri I, Suter S. Defective regulation of gap junctional coupling in cystic fibrosis pancreatic duct cells. J Clin Invest. 1999;103(12):1677-1684.

71. Poea-Guyon S, et al. The V-ATPase membrane domain is a sensor of granular $\mathrm{pH}$ that controls the exocytotic machinery. JCell Biol. 2013;203(2):283-298.

72. Verdugo P. Polymer biophysics of mucus in cystic fibrosis. In: Baum GL, ed. Cilia Mucus And Mucociliary Interactions. New York, New York, USA: Marcel Dekker;1998:167-190.

73. Baconnais S, et al. Abnormal ion content, hydration and granule expansion of the secretory granules from cytic fibrosis airway glandular cells.
Exp Cell Res. 2005;309(2):296-304.

74. Dickson EJ, Duman JG, Moody MW, Chen L, Hille B. Orai-STIM-mediated $\mathrm{Ca}^{2+}$ release from secretory granules revealed by a targeted $\mathrm{Ca}^{2+}$ and $\mathrm{pH}$ probe. Proc Natl Acad Sci U S A. 2012;109(51):E3539-E3548.

75. Han W, Li D, Stout AK, Takimoto K, Levitan ES. $\mathrm{Ca}^{2+}$-induced deprotonation of peptide hormones inside secretory vesicles in preparation for release. J Neurosci. 1999;19(3):900-905.

76. Cheng PW, Boat TF, Cranfill K, Yankaskas JR, Boucher RC. Increased sulfation of glycoconjugates by cultured nasal epithelial cells from patients with cystic fibrosis. JClin Invest. 1989;84(1):68-72.

77. al-Awqati Q, Barasch J, Landry D. Chloride channels of intracellular organelles and their potential role in cystic fibrosis. J Exp Biol. 1992;172:245-266.

78. Verdugo P. Supramolecular dynamics of mucus. Cold Spring Harb Perspect Med. 2012;2(11):1-14.

79. Carlyle BE, Borowitz DS, Glick PL. A review of pathophysiology and management of fetuses and neonates with meconium ileus for the pediatric surgeon. J Pediatr Surg. 2012;47(4):772-781.

80. Snouwaert JN, et al. An animal model for cystic fibrosis made by gene targeting. Science. 1992;257(5073):1083-1088.

81. Meyerholz DK, Stoltz DA, Pezzulo AA, Welsh MJ. Pathology of gastrointestinal organs in a porcine model of cystic fibrosis. Am J Pathol. 2010;176(3):1377-1389.

82. Borowitz D, et al. Gastrointestinal outcomes and confounders in cystic fibrosis. J Pediatr Gastroenterol Nutr. 2005;41(3):273-285.

83. King SL, Mohiuddin JJ, Dekaney CM. Paneth cells expand from newly created and preexisting cells during repair after doxorubicin-induced damage. Am J Physiol Gastrointest Liver Physiol. 2013;305(2):G151-G162.

84. Diwu Z, Chen C-S, Zhang C, Klaubert DH, Haugland RP. A novel acidotropic $\mathrm{pH}$ indicator and its potential application in labeling acidic organelles of live cells. Chem Biol. 1999;6(7):411-418. 